\title{
Florida Peach and Nectarine Varieties ${ }^{1}$
}

\section{Mercy Olmstead, Jose Chaparro, Pete Andersen, Jeff Williamson, and James Ferguson²}

The Florida stone fruit breeding program began in 1952, under the direction of Dr. Ralph Sharpe. The major goal of Dr. Sharpe's breeding program was to take advantage of the climate in Florida to provide early, high-quality fruit to the market (Sherman, Lyrene, and Sharpe 1996). In 1966, Dr. Wayne Sherman became leader of the stone fruit breeding program, and he continued to focus on breeding for low-chill peach cultivars with non-melting flesh that perform well in Florida's subtropical climate. The current stone fruit breeder, Dr. Jose Chaparro, has overseen and initiated research to bring in unique plant material that focuses on large, high-quality fruit with disease resistance and low chilling requirements.

The University of Florida has developed high-quality, lowchilling, early-maturing peach and nectarine cultivars that can be grown from the panhandle of Florida to as far south as Immokalee. Low-chilling cultivars can grow and produce fruit under Florida conditions that are much warmer in winter than in northern states. Furthermore, ripening of these cultivars during April and May ensures an early spring market window for tree-ripe fresh fruit in Florida before peaches and nectarines from other southeastern states and California come to market. Both commercial and dooryard recommended varieties span the growing season (Table 1).
Peaches and nectarines are the same species, Prunus persica, but nectarines differ from peaches in that they lack "peach fuzz." Therefore, the following discussion applies to both peaches and nectarines, but in most cases reference will be made only to peaches. Plums, the only other stone fruit for which we have suitable Florida cultivars, are covered in "Growing Plums in Florida," another fact sheet available at http://edis.ifas.ufl.edu/hs250.

\section{Fruit Developmental Periods and Chill Accumulation}

Early ripening ability is an important trait for Florida stone fruit cultivars. The period from fruit set to maturity, when the fruit can be harvested, is called fruit developmental period, or FDP. The FDP of current Florida peach cultivars is quite short: some of them will be mature and ready for harvest as soon as 60 days from fruit set. The FDP can vary with temperature during the growing season, with warmer temperatures compressing and cooler temperatures lengthening the FDP. Therefore, the FDP varies from season to season, and the numbers presented are averages over a number of years.

Low-chill peach cultivars are those that require fewer chill units (100-250 chill units) than those cultivars that originate from temperate climates. Moderate chill cultivars have been developed for north Florida, north central Florida

1. This document is Circ. 1159, a publication of the Horticultural Sciences Department, UF/IFAS Extension. First published November 1995 under the title, "Peaches and Nectarines for Central and North Florida." Revised May 2013.

Please visit the EDIS website at http://edis.ifas.ufl.edu.

2. Mercy Olmstead, Extension fruit specialist; Jose Chaparro, stone fruit breeder; Pete Andersen, professor, Horticultural Sciences Department, North Florida Research and Education Center, Quincy, FL; Jeff Williamson, professor, Horticultural Sciences Department; and James Ferguson, professor, Horticultural Sciences Department, retired; UF/IFAS Extension, Gainesville, FL 32611. W. B. Sherman, professor emeritus, Horticultural Sciences Department, contributed to earlier versions of this publication.

The Institute of Food and Agricultural Sciences (IFAS) is an Equal Opportunity Institution authorized to provide research, educational information and other services only to individuals and institutions that function with non-discrimination with respect to race, creed, color, religion, age, disability, sex, sexual orientation, marital status, national origin, political opinions or affiliations. U.S. Department of Agriculture, Cooperative Extension Service, University of Florida, IFAS, Florida A\&M University Cooperative Extension Program, and Boards of County Commissioners Cooperating. Nick T. Place, Dean 
and south central Georgia and require higher numbers of chill units (300-525 chill units). Chill units are variable across the state of Florida and decrease as one moves south in the state (Table 2). The chilling unit requirement is not always related to the FDP, and some cultivars require large amounts of chilling yet have a short FDP. For example, 'UFGlo' requires 450 chill units yet has an FDP of 80 days, while 'UFBest' requires less than 150 chill units and has an FDP of 95 days (Table 3).

There are several models used to calculate chill hours ( for examples please see Richardson, Seeley, and Walker 1974; Sharpe, Sherman, and Martsolf 1990; Weinberger 1956). One model in particular that defines a chill unit as 1 hour below $45^{\circ} \mathrm{F}\left(7^{\circ} \mathrm{C}\right)$ but above $32^{\circ} \mathrm{F}\left(0^{\circ} \mathrm{C}\right)$ works well for determining ranges of accumulation in low-chill peaches. The accumulation over a defined period (usually November-January in Florida) is termed chill unit accumulation. There are many sources from which to gather this data, including the Florida Automated Weather Network (http:// fawn.ifas.ufl.edu/) (Fraisse and Whidden 2010). The state of Florida has several zones with different chill unit accumulations (Figure 1) to aid in selecting a peach cultivar.

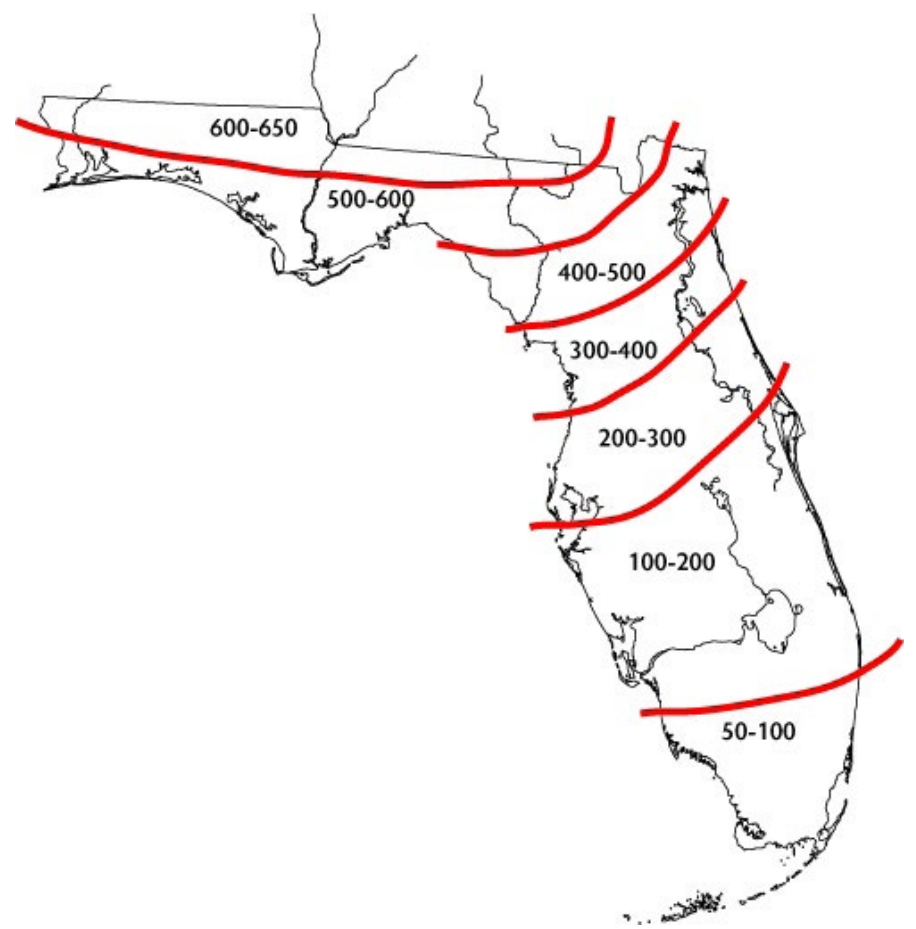

Figure 1. Chill Hour Accumulation in Florida (Below $45^{\circ} \mathrm{F}\left[7.2^{\circ} \mathrm{C}\right]$ Through February $10^{\text {th }}$ ).

Credits: Outline Map Courtesy of the Florida State Historical Society.

\section{Peach Tree Growth Habit and Cultivar Identification}

Peach trees vary in their growth habit, and often a combination of tree vigor, flower type, and leaf structure can be used to identify cultivars. Trees can have semi-spreading (e.g., 'UFOne') or semi-upright growth (e.g., 'Flordaprince') and can be either very vigorous (e.g., 'UFSun') or moderately vigorous (e.g., 'Sunbest') in canopy growth. Flowers on certain peach cultivars can be showy, with large, pink petals; flowers on other cultivars are non-showy, with smaller, redder petals (Figure 2). Leaf glands at the base of the leaf near the petiole can also be used in the identification process. Leaf glands may be absent (eglandular), or they may be globose (round) or reniform (kidney-shaped) (Figure 3).

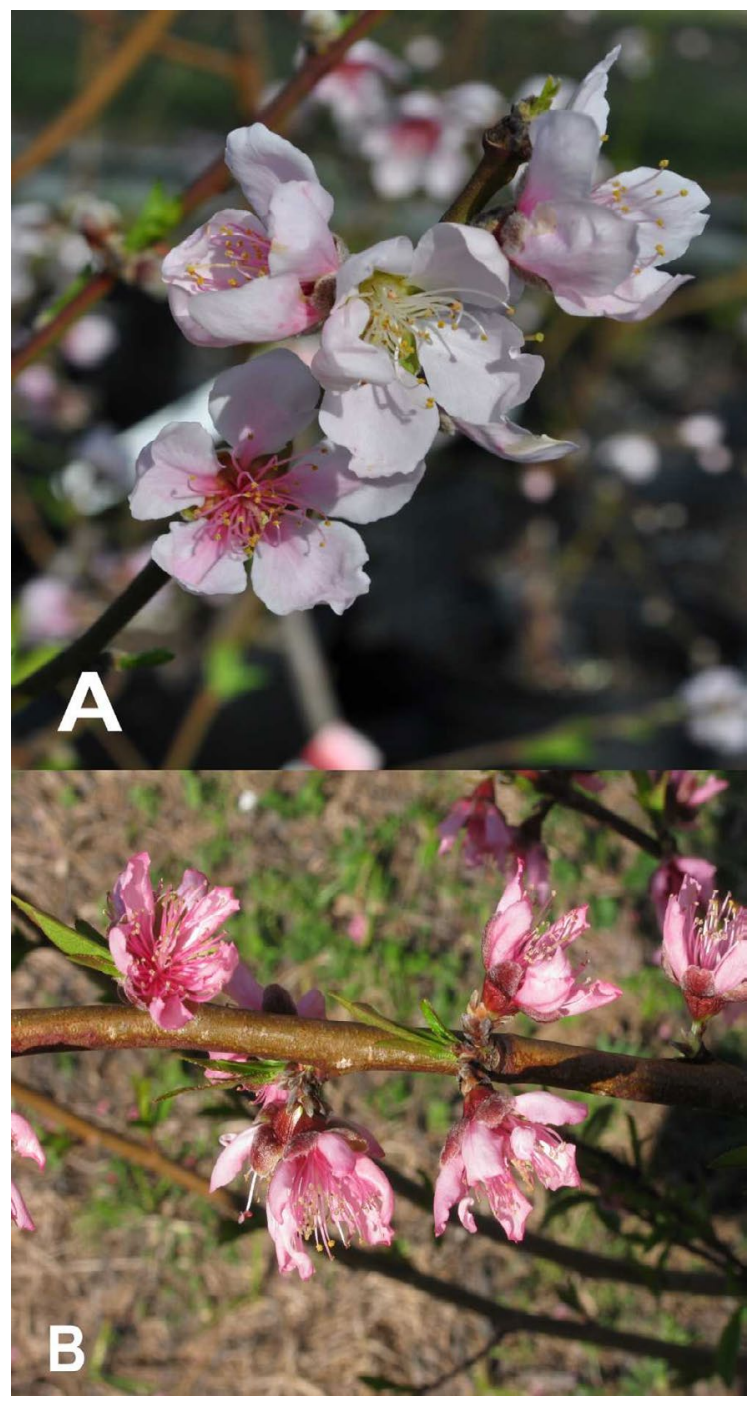

Figure 2. Showy (a) and non-showy (b) peach flowers.

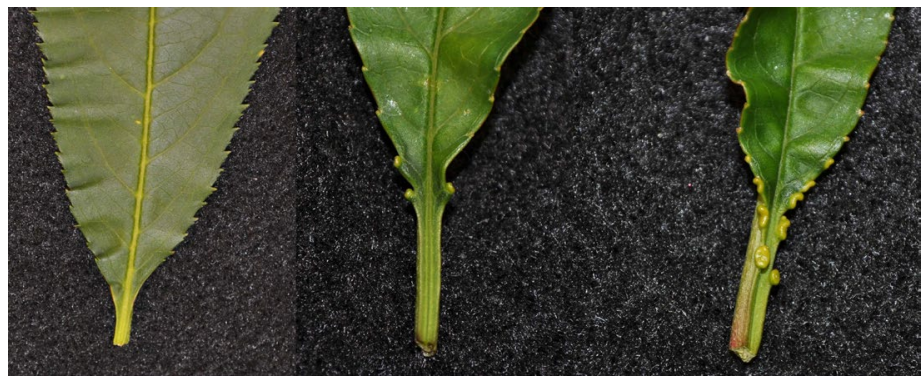

Figure 3. Eglandular (a), globose (b) and reniform (c) leaf glands on peach leaves. 


\section{Peach Flesh and Pit Descriptions}

Peaches are typically available in two different flesh types, melting and non-melting. Melting-flesh peaches undergo a rapid softening of the flesh as the fruit ripen. Historically, this type of fruit has been used for fresh fruit production. Non-melting-flesh peaches are characterized by a firm flesh phenotype that softens slowly. Non-melting-flesh peaches had primarily been used for processing; however, improvements in flavor and texture through breeding at the University of Florida and elsewhere have resulted in nonmelting-flesh peaches with superior fruit characteristics for eating fresh.

Melting-flesh cultivars are typical of those popular at farm stands and u-pick operations in which the fruit are picked tree ripe. They typically do not ship very well as they approach physiological ripeness because of their tendency to bruise easily. Thus, when intended for distant marketing, melting-flesh peaches are harvested much earlier to withstand transport within the marketing chain. In those cases, sugar levels (often measured as ${ }^{\circ} \mathrm{Brix}$ ), flavor, and color will not be as well developed as in tree ripe fruit. Fruit quality is an important consideration for consumers in deciding whether to make repeat purchases (Crisosto 2002); however, acceptable fruit quality can be difficult to achieve with early-ripening cultivars (Sharpe, Webb, and Lundy 1954). The UF program focuses on breeding non-melting-flesh peaches that are firm even when ripe.

Clingstone and freestone are two terms that describe the relative tendency of the flesh to adhere to the pit. In a clingstone peach, the flesh adheres to the pit so that the pit cannot be easily extracted from the flesh when the fruit is sliced in half. All non-melting-flesh peach cultivars released by the University of Florida are clingstone or semi-clingstone (the flesh of semi-clingstone peaches becomes easier to separate from the pits as the fruit ripen). Peach fruit with flesh that separates easily from the pit are described as freestone. Typically, melting-flesh peach cultivars are semi-freestone or freestone; however it is possible to have a melting-flesh, clingstone peach. Although there is some variation in the degree of flesh adherence (e.g., semi-freestone or semi-clingstone), no non-meltingflesh, freestone peach cultivars are available.

Peaches are considered a climacteric fruit, which means that fruit are able to continue ripening after they are harvested, although the sugar level and therefore perceived sweetness will not increase. Often, peaches that consumers purchase may be firm, but they will soften and develop more aroma when placed on a counter or in a fruit bowl. Fruit that are allowed to ripen on the tree have better fruit quality by many standards of measurement, but particularly sweetness. Florida's unique environment allows commercial growers to harvest "tree-ripe," non-melting-flesh cultivars that are firm and possess very high-quality.

\section{Fruit Descriptions and Grading}

Fruit size can be affected by genetic potential, crop load, climatic conditions, cultural and related management practices, and soil type. Fruit yield per tree can also be affected by tree age and size, and by the amount of fruit thinning completed after fruit set. It is especially difficult to breed cultivars that produce large fruit with a short FDP because each phenological stage (cell division, pit hardening, final fruit swell, and cell elongation) in fruit development requires a certain time frame. Cultivars that have a longer FDP will tend to have larger fruit because these phenological stages are able to occur over relatively long periods compared to cultivars with shorter FDPs. In addition, warm temperatures can compress these phenological stages, which can also result in smaller fruit (Lopez and DeJong 2007). Florida peach fruit size can best be increased by adequate thinning at the earliest stage after frost danger is past and by supplemental irrigation, especially during final fruit swell.

Fruit Color refers to ground color (background color) and blush (red color). When peach fruit ripen, the ground color changes from green to yellow. Changes in ground color are not affected by fruit position on the tree or exposure to sunlight, so ground color can therefore be used by harvesting crews to indicate fruit maturity. Changes in blush, or red coloring in the fruit skin or flesh, are affected by fruit position in the canopy and sunlight interception. The more exposed to the sun a fruit is, the greater the intensity of its blush. A high percentage fruit red blush $(>70 \%)$ and bright yellow ground color are most desirable for attractiveness and sales in U.S. markets. Percentage red blush is at least $50 \%$ for many recently released cultivars (Table 4). If the ground color becomes difficult to see due to very high percentage of fruit red blush, the occurrence of slight softening at the fruit tip can be used to determine the correct harvest time.

Total attractiveness of fruit is related to shape, size, color, and flesh browning. Fruit shape, firmness, taste, flesh browning, and overall attractiveness are also rated subjectively. Round to oblong fruit shape is desirable, and ratings are lowered by the degree of protruding tips and sutures. Fruit with high aroma, moderate acidity, and sweet taste are the most desirable. A high degree of rapid browning from 
cuts and bruises on soft ripe fruit is not desirable. Most recent releases from the UF breeding program have little or no browning of the flesh.

\section{Peach and Nectarine Breeding Efforts}

Cultivars adapted to Florida have been developed by two programs. The UF breeding program has focused on the breeding of cultivars with chilling requirements ranging from approximately 200 to 450 chill hours. A second cooperative breeding program located in Georgia at the University of Georgia's Attapulgus Research and Education Center involving scientists from University of Florida (Dr. Jose Chaparro), the University of Georgia (Dr. Patrick Conner) and USDA-ARS in Byron, GA (Dr. Thomas Beckman) is focused on breeding peaches with chilling requirements ranging from 350 to 650 chill hours.

\section{Peach Rootstocks}

All stone fruit grown in Florida are grafted to rootstock because of the presence of the peach root-knot nematode (Meloidogyne floridensis). 'Flordaguard' is a nematoderesistant rootstock that is currently recommended for both commercial and dooryard production. The distinctive red leaves of 'Flordaguard' allow growers to easily identify it in the nursery as root suckers emerge during the first 2 to 3 years after planting. 'Sharpe' rootstock can also be used as a peach root-knot nematode-resistant rootstock; however, it has been criticized for small fruit size. Several other rootstocks are being tested in conjunction with the USDAARS Peach Rootstock Breeding Program in Byron, GA. For more information on rootstocks for stone fruit, reference http://edis.ifas.ufl.edu/hs366.

\section{Commercial Peach and Nectarine Cultivars}

A major focus of the UF Stone Fruit Breeding program has been the development of non-melting-flesh cultivars that can be harvested tree ripe. Non-melting-flesh commercial cultivars that have been released from the University of Florida breeding program begin with the prefix "UF," i.e., 'UFO,' 'UFBest', 'UFSharp', 'UFBeauty', 'UFGlo, 'UFSun', and 'UFOne' (Table 4). In addition, the non-melting-flesh nectarine cultivars 'UFQueen' and 'UFRoyal' have been released from the UF program. For growers in northern Florida and southern Georgia, the cooperative breeding effort program of the University of Florida, University of Georgia and USDA-ARS mentioned previously, has released 'Gulfsnow', 'Gulfprince,' 'Gulfking,' 'Gulfcrest', and
'Gulfcrimson' peaches, which require a higher chilling unit accumulation (350-525 chill units). Today, these and other cultivars released by the UF Stone Fruit Breeding Program are grown in Australia, Egypt, Morocco, South Africa, and other locations around the world.

\section{Cultivar Descriptions}

One of the most important decisions taken by a grower is to ensure that a chosen cultivar is adapted to a particular site. Particular peach cultivars destined for commercial production are recommended for each area in order to ensure that the cultivars' chilling unit requirements would be met in most years. Cultivars with higher chill unit requirements can be grown, but their required chill units will not accumulate every year, which will result in inconsistent cropping.

Listed below are recommended peach, nectarine, and plum cultivars for commercial scale production, with the goal of taking advantage of an early market window (April-May).

\section{NORTHERN AND NORTH CENTRAL FLORIDA 'Flordabest' -250 chill units}

'Flordabest' was released and patented in 2009 and has a FDP of 82 days from fruit set to harvest. The fruit develop 90-100\% blush, making them very attractive. The fruit are large, and have melting, but uniformly firm yellow flesh, and semi-clingstone pits. The fruit ripens about 7-10 days earlier than the standard peach cultivar 'TropicBeauty' in Gainesville, Florida. It is recommended for trial in Gainesville and south to Interstate 4 .

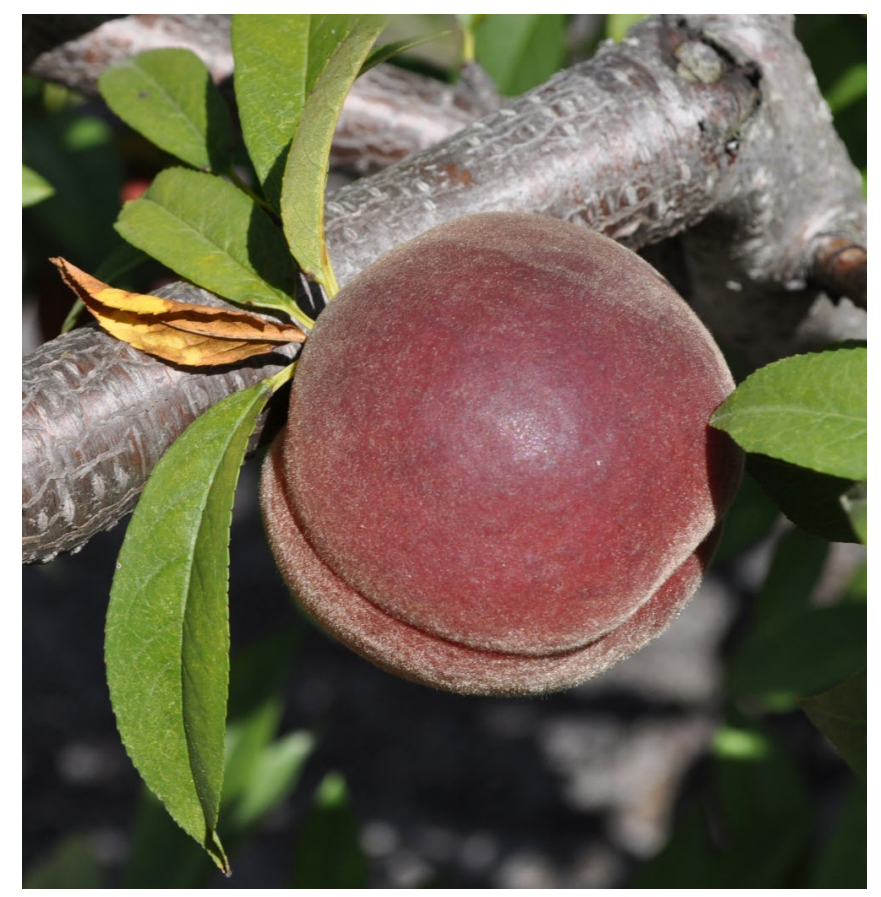

Figure 4. 'Flordabest' 


\section{'UFO'-250 chill units}

'UFO' is a non-melting-flesh, peento-type peach with a unique donut shape. It was patented in 2002 and produces large, vigorous trees with a semi-upright growth habit.

'UFO' produces moderately heavy crop loads of large, firm fruit with yellow flesh and semi-freestone pits that have an FDP of 95 days. The skin develops $50-70 \%$ blush. This cultivar is particularly susceptible to ethylene that is released during dormant pruning, which can result in significant flower bud abortion. Thus, pruning is only recommended during the summer period.

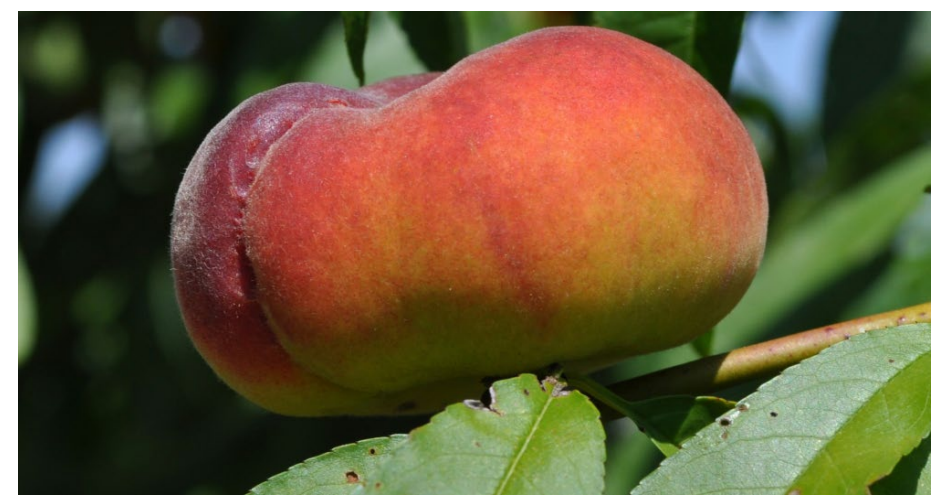

Figure 5. 'UFO'

\section{'Gulfking'-350 chill units}

'Gulfking' is a non-melting-flesh cultivar that was jointly released and patented by the joint UF, UGA, and USDAARS breeding program in 2004 (Krewer et al. 2005). The fruit have exceptional color, with $80-90 \%$ red skin with stripes over a deep yellow ground color. The fruit are very firm with yellow flesh and are clingstone. The FDP is 77 days, and the fruit develop good size, shape and color in north Florida.

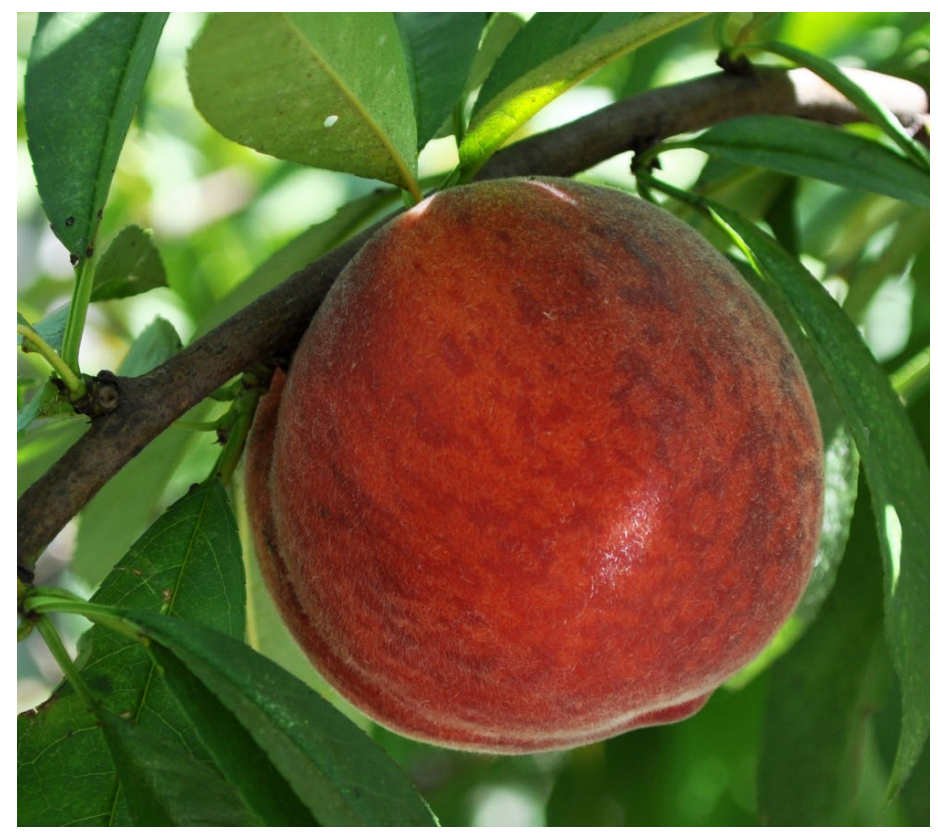

Figure 6. 'Gulfking'

\section{'Gulfsnow'-400 chill units}

'Gulfsnow' is a 2012 joint release from the University of Florida, University of Georgia, and USDA-ARS breeding program. Trees of 'Gulfsnow' are vigorous and semi-spreading, producing white, non-melting-flesh fruit. 'Gulfsnow' fruit are large, round, and attractive with a $50-60 \%$ blush over a cream background. The fruit are clingstone, with medium-sized, red pits and have a FDP of 110 days.

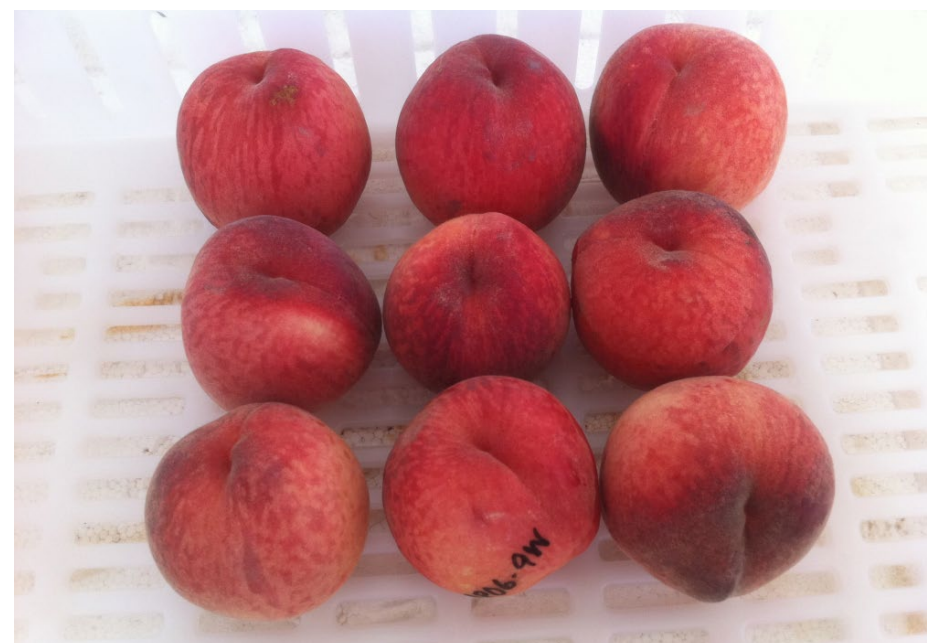

Figure 7. 'Gulfsnow'

\section{'Gulfcrimson' -400 chill units}

'Gulfcrimson' is the third in a series of cultivars released and patented by the joint UF, UGA, and USDA-ARS stone fruit breeding program, specifically in 2009 (Krewer et al. 2008). 'Gulfcrimson' fruit are large for an early-ripening cultivar and have a yellow ground color with $80-90 \%$ red skin. 'Gulfcrimson' ripens with the standard peach cultivar 'JuneGold' in Attapulgus, Georgia, with an FDP of 95 days and highly consistent cropping, making it a good midseason replacement for 'JuneGold'. It also crops reliably in north Florida. Photo courtesy of USDA-ARS.

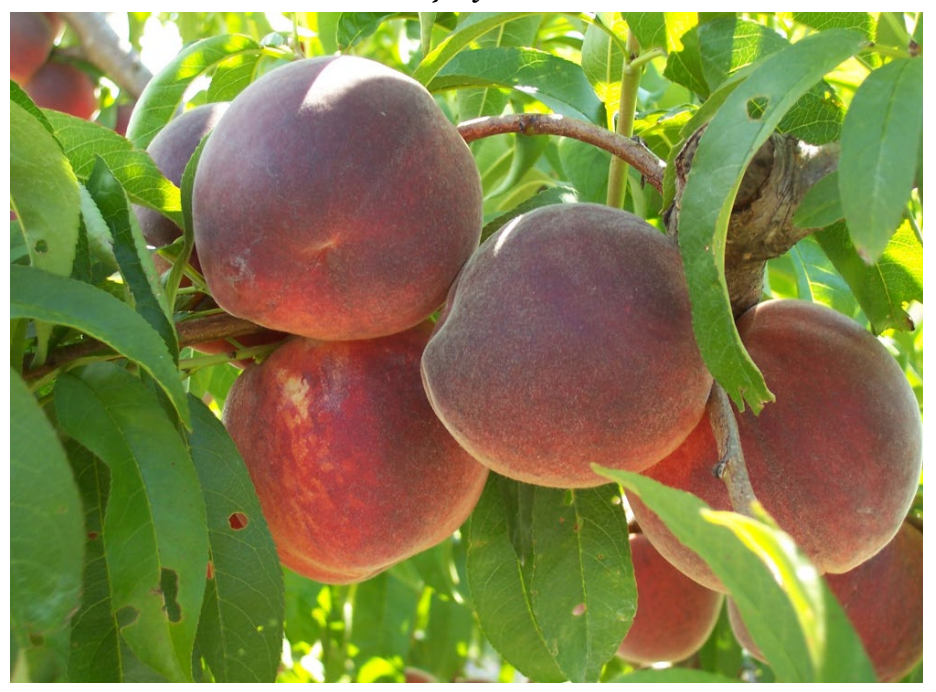

Figure 8. 'Gulfcrimson' 


\section{'UFGlo'-400 chill units}

'UFGlo' is a white-flesh, non-melting peach that was released in 2009. 'UFGlo' fruit are large, develop 80-90\% blush over the entire fruit, and are clingstone. The FDP is 80-85 days. 'UFGlo' ripens in areas where the standard cultivar 'Flordaking' does well, and it complements 'UFSharp' peaches in north central Florida. It produces consistent crops with good yields in north Florida.

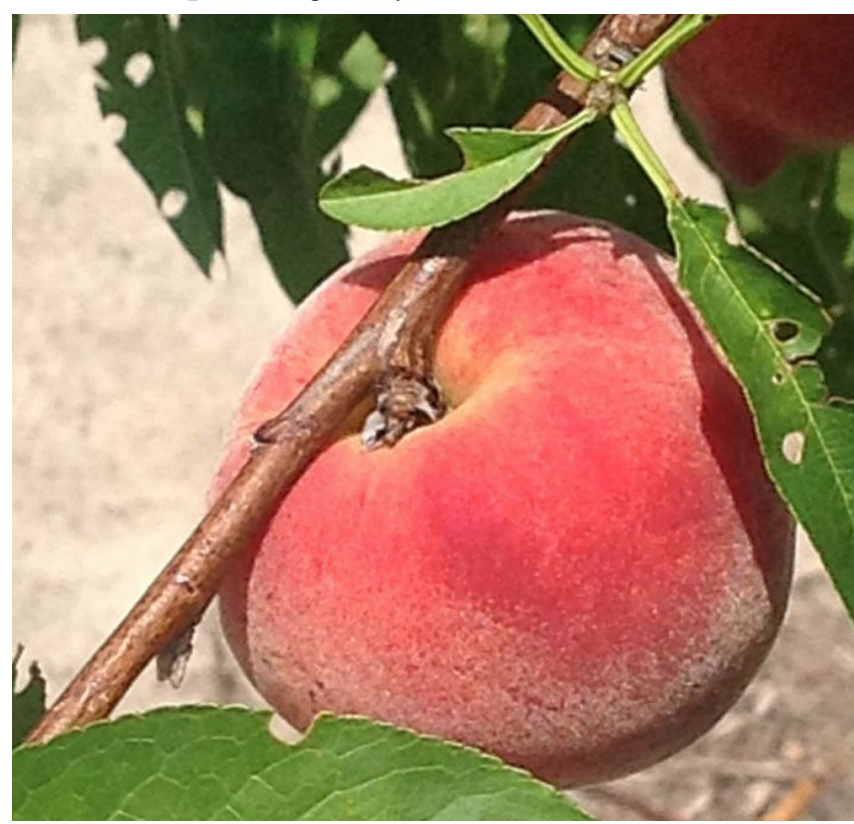

Figure 9. 'UFGlo'

\section{'Gulfcrest' - 525 chill units}

'Gulfcrest' is a 2004 release from the UF, UGA and the USDA-ARS joint breeding program. It has an FDP of 62-75 days and has non-melting flesh with a clingstone pit. Ripe 'Gulfcrest' fruit have 90-95\% red color over deep yellow to orange ground color and ripen in early to mid-May in southern Georgia. 'Gulfcrest' fruit can be variable in size on the tree and can produce "twiggy" branch growth.

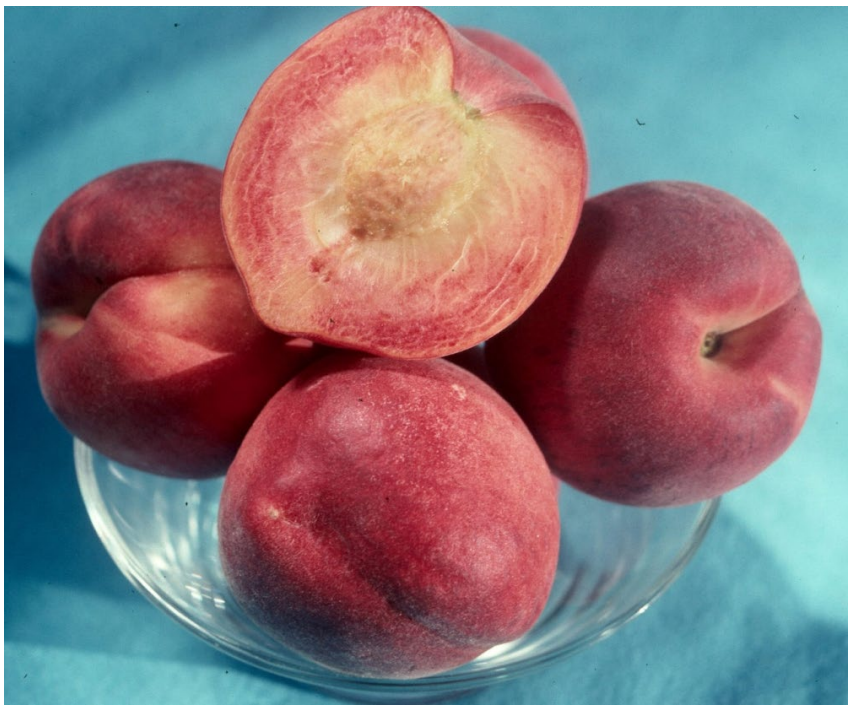

Figure 10. 'Gulfcrest'
'Gulfcrest' is adapted to extreme northern Florida and southern Georgia. Photo courtesy of USDA-ARS.

\section{NECTARINE CULTIVARS}

\section{'Sunbest' -225 chill units}

'Sunbest', released in 2001, is a patented nectarine cultivar with yellow, melting flesh, and a semi-freestone pit. It develops $90-100 \%$ bright red blush over a yellow ground color, and has a FDP of 85-90 days. 'Sunbest' ripens in early May (Gainesville, FL), about 3 days before the standard 'Sunraycer' nectarine cultivar. It is superior to and a good replacement for 'Sunraycer' nectarine.

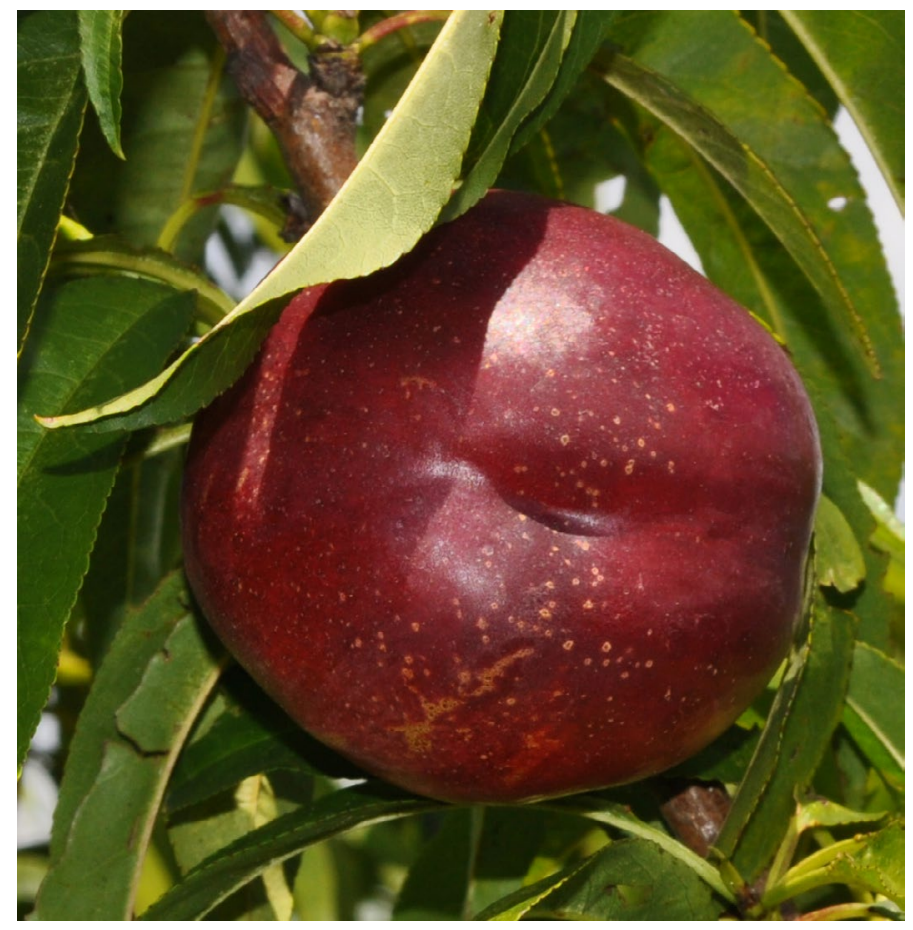

Figure 11. 'Sunbest'

\section{'UFRoyal'-250 chill units}

'UFRoyal' is a yellow flesh, non-melting nectarine, with a FDP of 85 days. 'UFRoyal' fruit are large, with $100 \%$ red skin, and a semi-clingstone pit. Fruit are symmetrically oval and ripen approximately 1 week before 'UFQueen' (below) in early May (Gainesville, FL). 'UFRoyal' fruit have excellent firmness and flavor, with excellent shipping potential. 


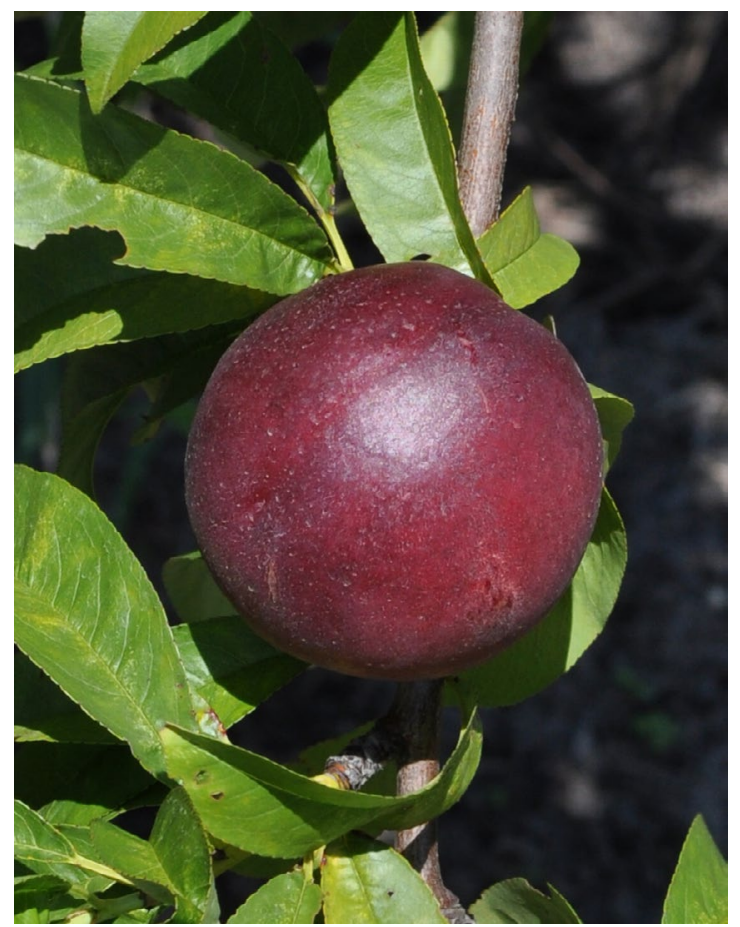

Figure 12. 'UFRoyal'

\section{'UFQueen'-250 chill units}

'UFQueen' is a regular bearer of early, large fruit in north central Florida, with an FDP of 95 days. 'UFQueen' trees are semi-upright and are easily pruned to an open vase system. The fruit have non-melting flesh with clingstone pits and yellow flesh color. The fruit are slightly oval with a slight tip and develop $80-100 \%$ red skin over a yellow background. 'UFQueen' fruit ripen about 1 week after the standard 'Sunraycer' nectarine cultivar in mid-May in Gainesville, Florida.

\section{CENTRAL AND SOUTH CENTRAL FLORIDA 'UFSun'-100 chill units}

'UFSun' is a non-melting-flesh peach cultivar released in 2004 (Rouse et al., 2004). 'UFSun' trees bear heavy annual crops of early-season, medium-sized fruit, with yellow flesh and clingstone pits. 'UFSun' fruit are uniformly symmetrical and develop 50-60\% red skin with darker red stripes. 'UFSun' fruit ripens with that of the standard peach cultivar 'Flordaprince' at Immokalee and Gainesville, Florida with an FDP of 80 days.

\section{'UFBest'-100 chill units}

'UFBest' One of the newest cultivars released by the UF breeding program (2012), this non-melting-flesh cultivar produces heavy annual crops of large fruit. 'UFBest' fruit develop 95-100\% red skin over a yellow ground color, and the flesh is yellow with clingstone pits. 'UFBest' ripens 1 week earlier than 'UFSun' (mid-April) in Gainesville, Florida, with a FDP of 85 days.

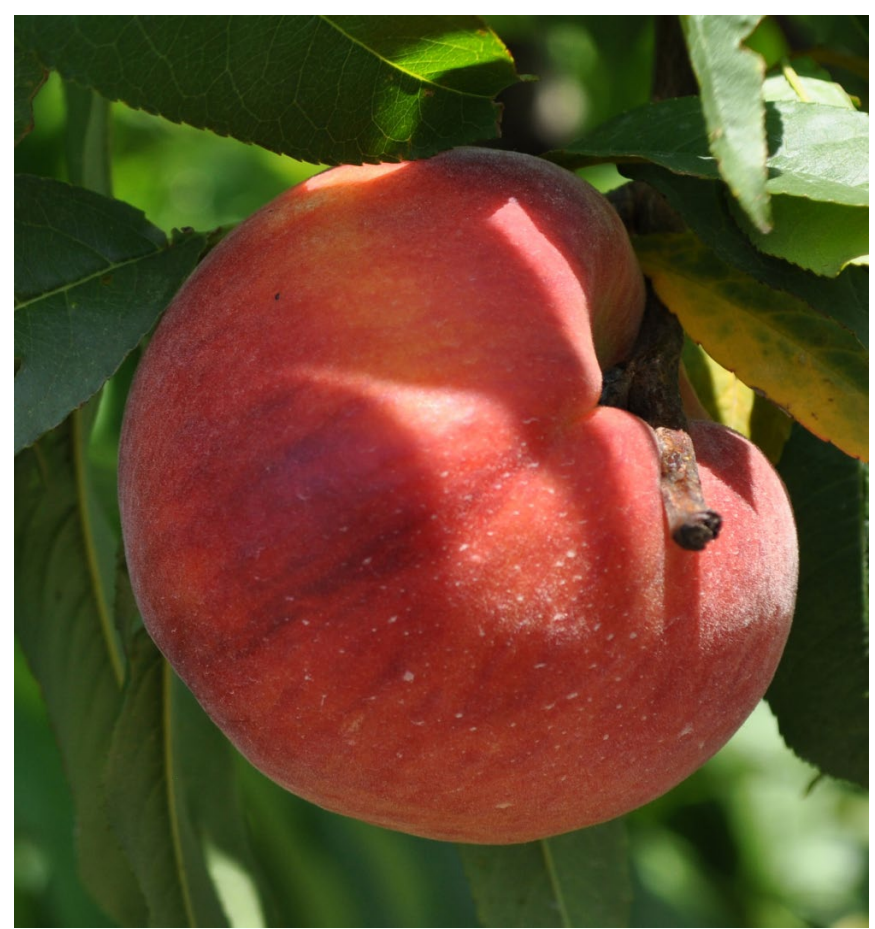

Figure 13. 'UFSun'

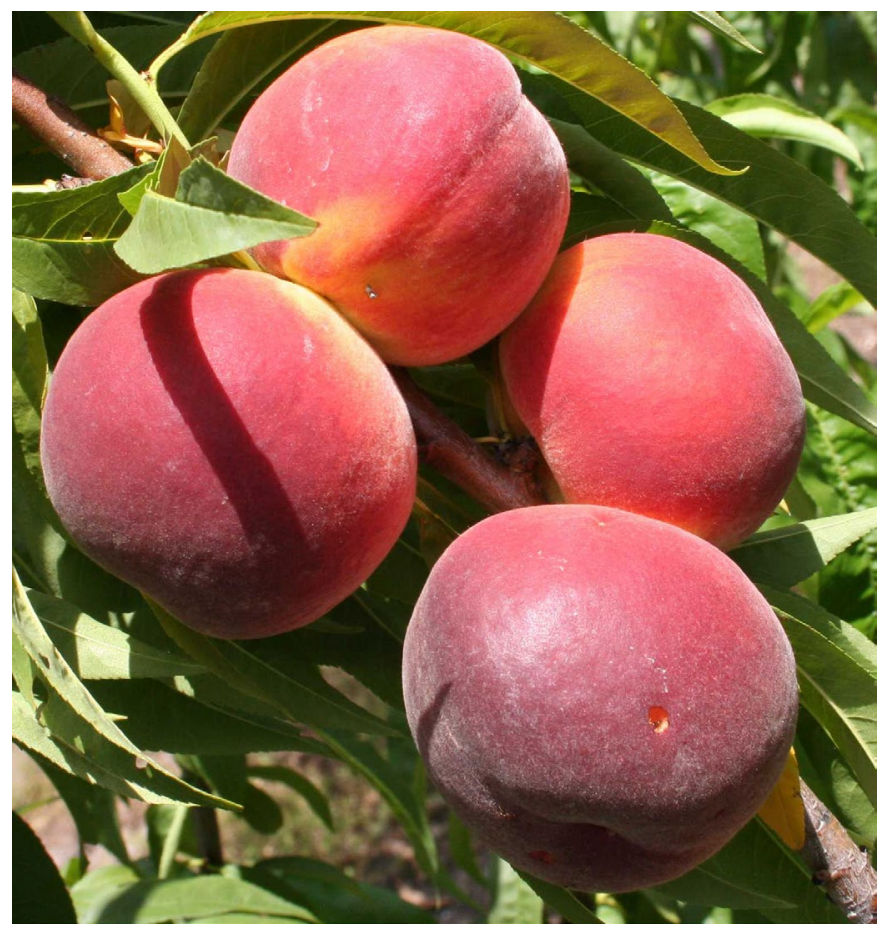

Figure 14. 'UFBest' 


\section{‘TropicBeauty' -150 chill units}

'TropicBeauty' is a non-patented cultivar released jointly by the University of Florida and Texas A\&M in 1989. The medium-sized, semi-freestone fruit have yellow, melting flesh and develop 70\% blush over a yellow ground color. 'TropicBeauty' ripens between 'UFSun' and 'UFOne' and has a FDP of 89 days.

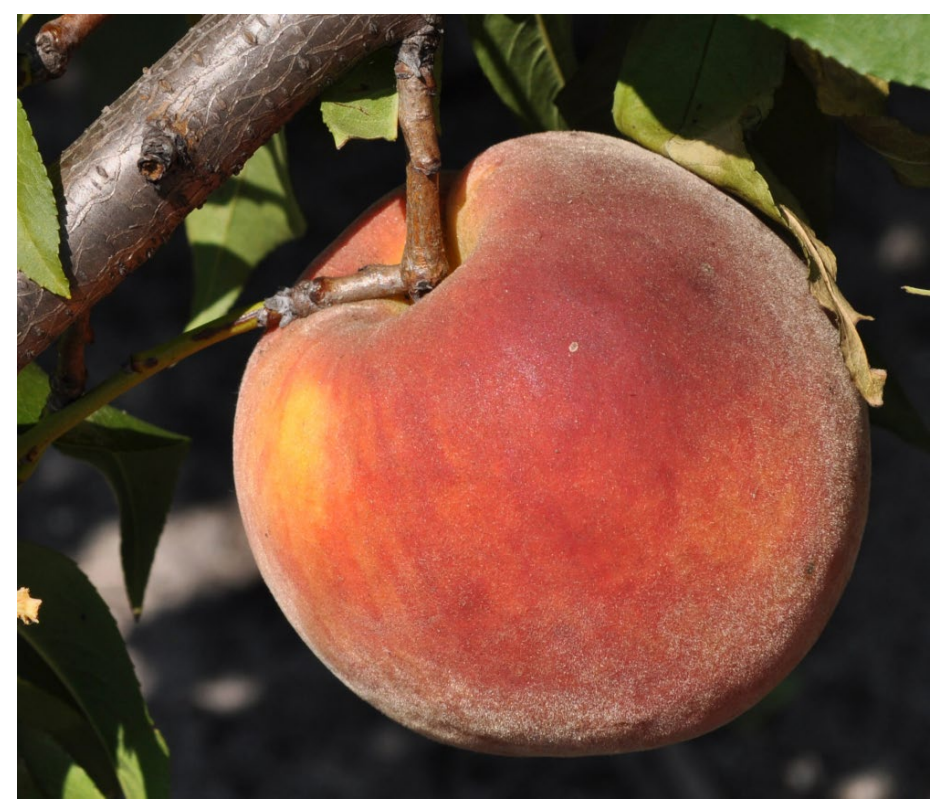

Figure 15. 'TropicBeauty'

\section{'UFBeauty' - 200 chill units}

'UFBeauty' is a peach cultivar released in 2002 with fruit that have non-melting-flesh, clingstone pits, and very symmetrical shape. The flesh of 'UFBeauty' fruit is yellow and very firm, and the skin color is near $100 \%$ red, with darker red stripes. 'UFBeauty' ripens 3 to 4 days after 'UFGold'

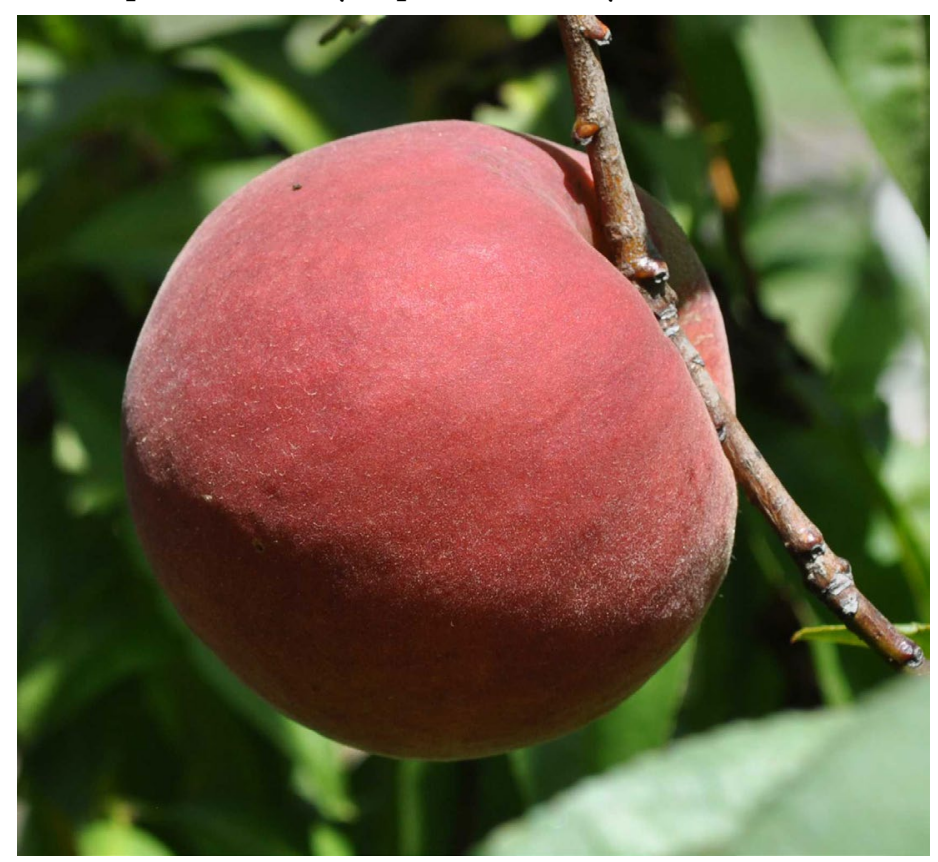

Figure 16. 'UFBeauty' in Gainesville, Florida with a FDP of 82 days. Cropping of 'UFBeauty' has been unreliable in south Florida when night temperatures during the bloom period are higher than $57^{\circ} \mathrm{F}$ $\left(14^{\circ} \mathrm{C}\right)$.

\section{'UFOne'-250 chill units}

'UFOne' is a non-melting-flesh cultivar released by UF in 2008. 'UFOne' fruit are medium-large, and the trees regularly bear large crops of marketable fruit. 'UFOne' fruit are very firm with yellow flesh and semi-clingstone pits and develop $40 \%$ red blush over a yellow ground color. 'UFOne' fruit have a fairly long FDP of 95 days and ripen with 'UFBeauty' (early May) in Gainesville, Florida.

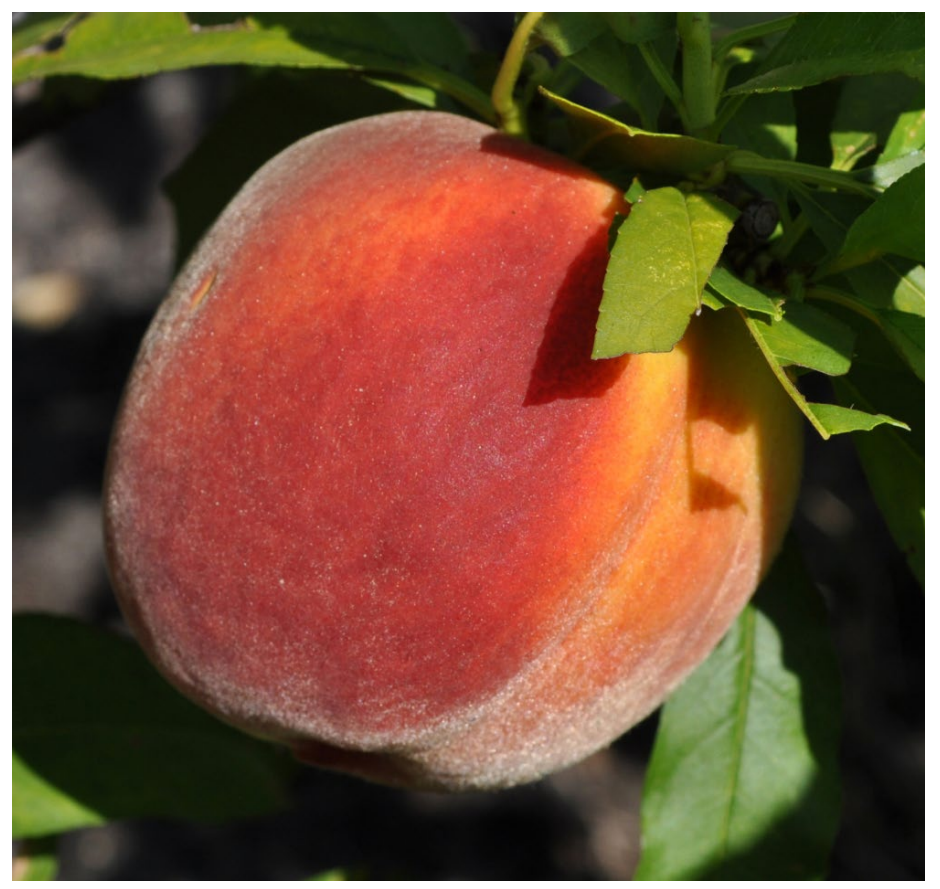

Figure 17. 'UFOne'

\section{Backyard/Dooryard Peach and Nectarine Cultivars}

Melting-flesh backyard cultivars 'Flordaprince,' 'Flordaglo', 'TropicSnow', 'Flordawn', 'Flordacrest', and 'Flordaking' (Table 2) can be found in many nurseries and large stores. These are all non-patented cultivars. Non-melting-flesh peach cultivars for backyard production include 'UFGold', 'UF2000', 'UFBlaze', and 'Gulfprince'.

\section{NORTH AND NORTH CENTRAL FLORIDA}

\section{'UF2000'-300 chill units}

'UF2000' is a yellow-flesh, non-melting, clingstone peach, released in 2000 . Trees are highly vigorous with a semispreading growth habit, and produce heavy annual crops of moderately large fruit. 'UF2000' fruit are symmetrically shaped and develop 50-70\% solid red skin over a yellow 
background. 'UF2000' fruit ripen mid-season, with harvest occurring from 15-18 days before 'UFGold' in mid-late May in Gainesville, Florida.

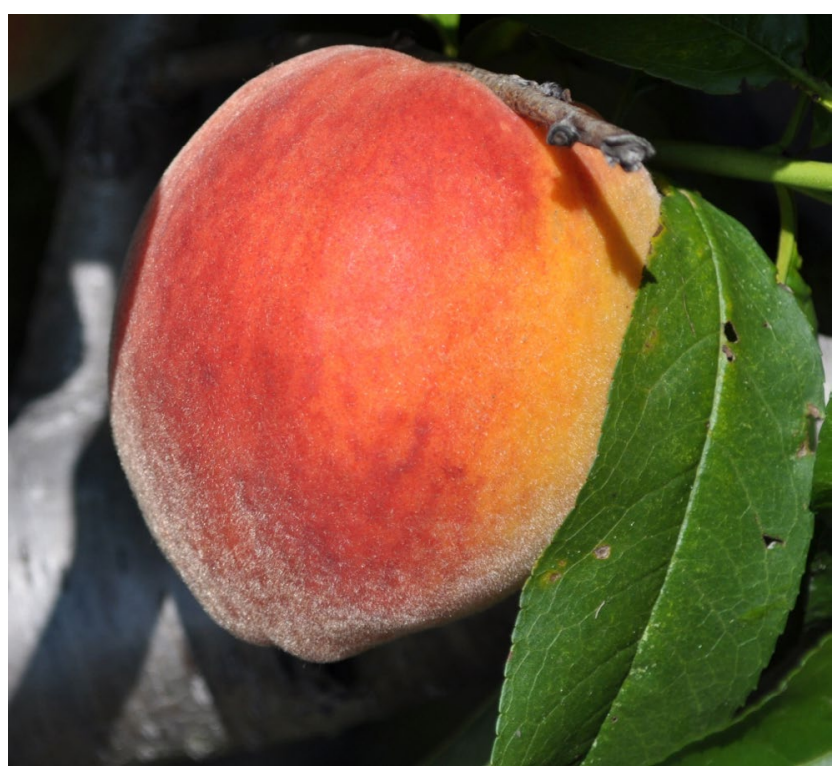

Figure 18. 'UF2000'

\section{'UFBlaze' -300 chill units}

'UFBlaze' is a non-melting-flesh, clingstone peach cultivar released in 2002. Trees are highly vigorous, with a semispreading nature. 'UFBlaze' trees produce heavy annual crops of large, early ripening, attractive fruit with bright red skin over $80-90 \%$ of a bright yellow-orange background and yellow flesh. Fruit are uniform and symmetrical, and they ripen about 7 to 10 days after 'UFGold' in early to mid May in Gainesville, Florida with a FDP of 83 days.

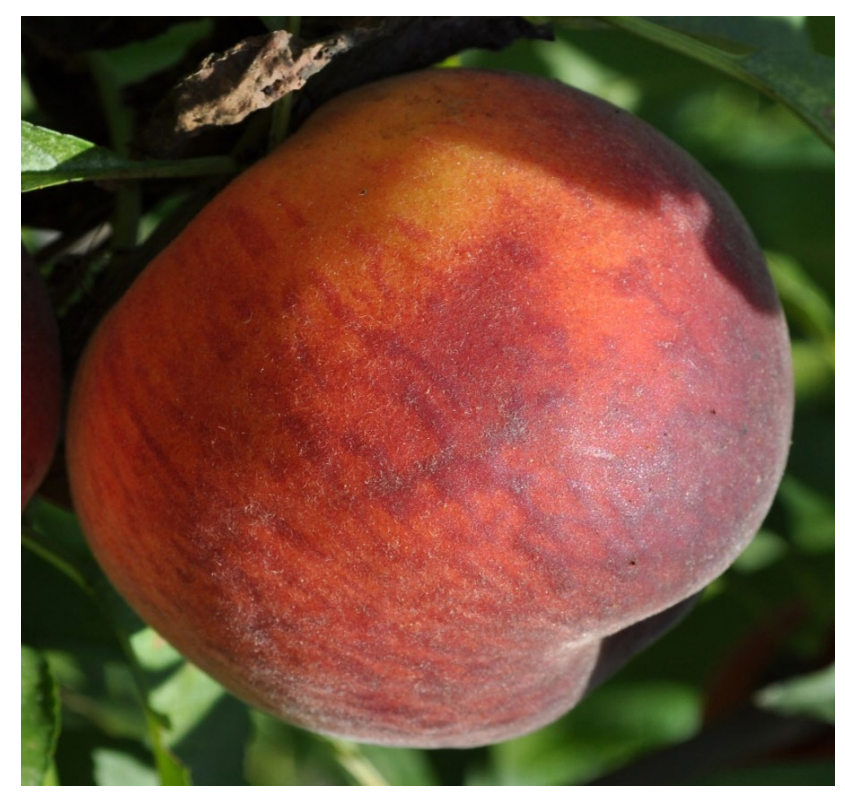

Figure 19. 'UFBlaze'

\section{'Flordadawn'-300 chill units}

'Flordadawn' is a melting-flesh non-patented peach cultivar released in 1989. 'Flordadawn' trees are vigorous and produce large numbers of flowers with moderately high fruit set. The bloom period of 'Flordadawn' is extended, which can help with fruit set during early spring frosts. The FDP of 'Flordadawn' is 60 days, which is the shortest of any named peach variety. Fruit of 'Flordadawn' develop $80 \%$ red blush, and have yellow flesh with a semi-clingstone pit. However, light crop loads have resulted in as much as $50 \%$ split pit incidence. 'Flordadawn' can often be found in large stores and nurseries for backyard plantings.

\section{'UFSharp'-325 chill units}

'UFSharp' is a patented, non-melting-flesh clingstone peach cultivar that was released in 2006. 'UFSharp' trees are vigorous, semi-spreading in nature, and productive. 'UFSharp' fruit develop $60 \%$ red blush over a deep yellow to orange ground color. 'UFSharp' has reliable cropping with excellent fruit size, shape, and firmness, and an FDP of 105 days.

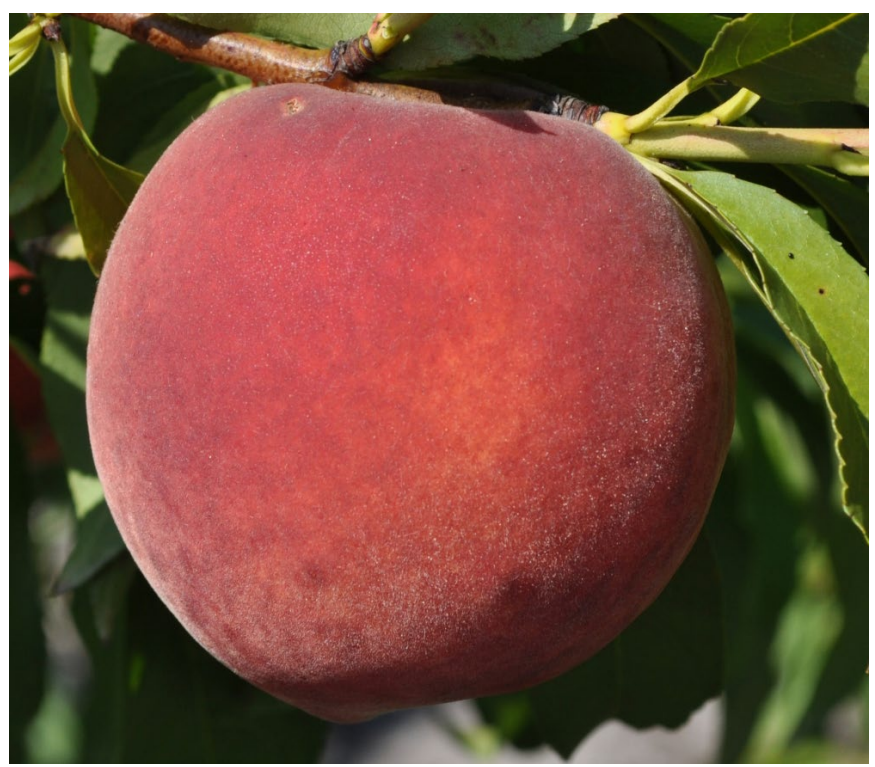

Figure 20. 'UFSharp'

\section{'Flordacrest'-350 chill units}

'Flordacrest' is a melting-flesh semi-clingstone peach cultivar released in 1988. 'Flordacrest' trees are vigorous with a spreading habit. 'Flordacrest' fruit have yellow flesh and develop $60-80 \%$ red blush over a bright yellow ground color. It is the best melting-flesh peach currently available for north Florida. It ripens after 'Flordaking' in north Florida, in early May in Gainesville, Florida with a FDP of 75 days. 


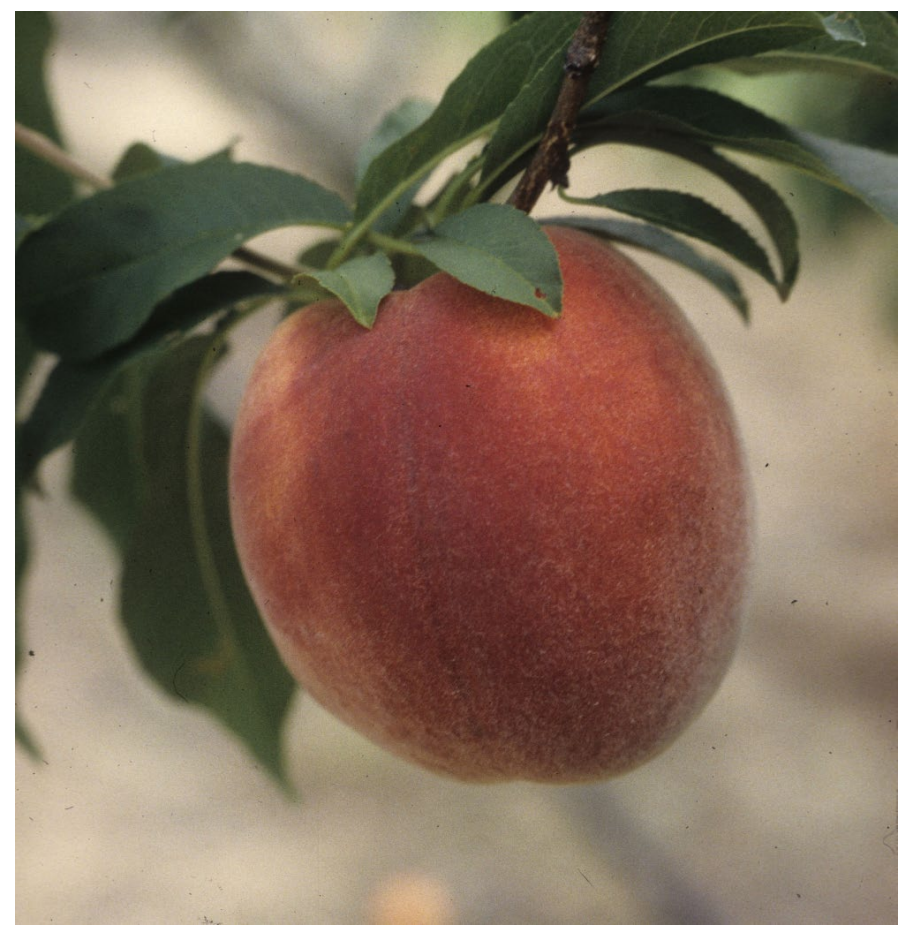

Figure 21. 'Flordacrest'

\section{'Gulfprince'-400 chill units}

'Gulfprince' was jointly released by the University of

Florida, University of Georgia, and USDA-ARS in 2002.

Trees of 'Gulfprince' are large and vigorous with a spreading growth habit. 'Gulfprince' fruit are uniform and symmetrical and develop 45-55\% solid red skin. Fruit have non-melting, yellow flesh with clingstone pits. 'Gulfprince' fruit has exhibited some slight browning due to oxidation on soft, ripe fruit. The FDP is 110 days. Photo courtesy of USDA-ARS.

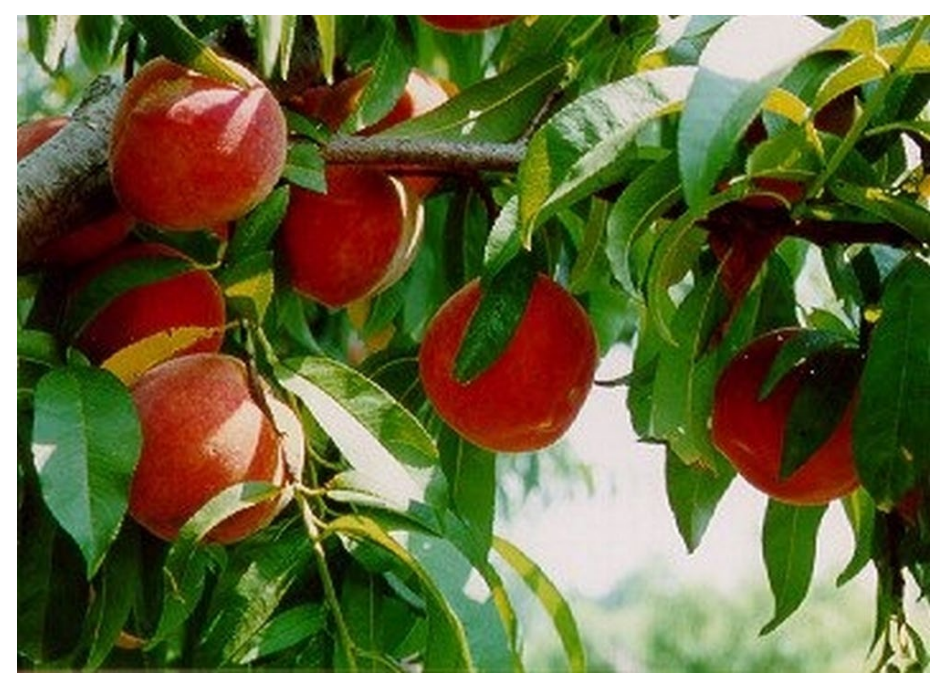

Figure 22. 'Gulfprince'

\section{'Flordaking'-450 chill units}

'Flordaking' is an older cultivar released in 1978. It is not patented and is a good selection for backyard production, with large fruit for a mid-season peach cultivar and moderate resistance to bacterial spot. Fruit of 'Flordaking' have yellow, melting flesh and clingstone pits. 'Flordaking' fruit develop 70\% red blush over a yellow ground color. 'Flordaking' has an FDP of 65-70 days and ripens in early May (Gainesville, FL). One disadvantage of 'Flordaking' fruit is high incidence of split pits when crop loads are low.

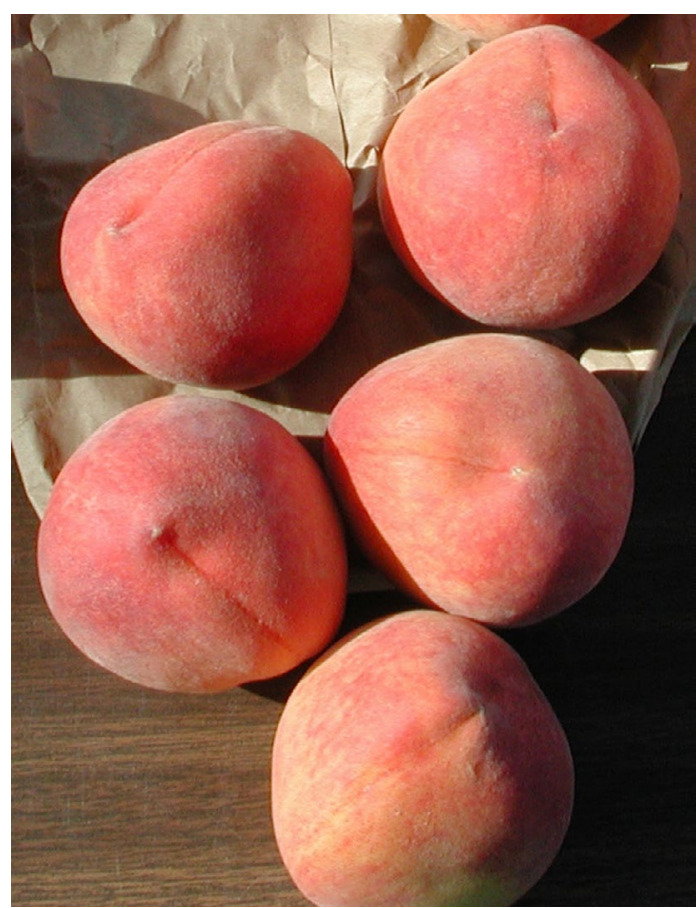

Figure 23. 'Flordaking'

\section{NECTARINE CULTIVARS}

\section{'Sunraycer' -275 chill units}

'Sunraycer' is a non-patented melting-flesh nectarine cultivar released in 1993. Trees are vigorous and semispreading, responding well to open-center pruning systems.

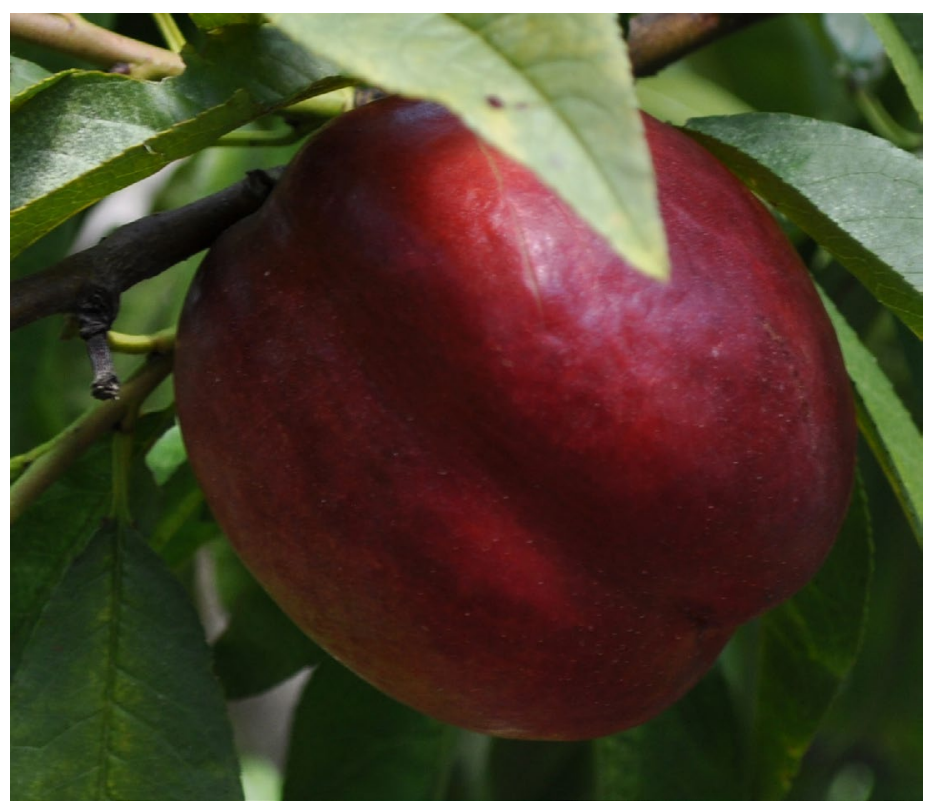

Figure 24. 'Sunraycer' 
'Sunraycer' produces large, semi-clingstone fruit with good firmness resistance to bacterial spot. 'Sunraycer' fruit develop $80-100 \%$ brilliant red blush over a bright yellow ground color and are oval with no sharp tips or suture bulges. 'Sunraycer' has an 85 day FDP and ripens in early May in Gainesville, Florida.

\section{'Sunbest'-225 chill units}

'Sunbest' is a patented melting-flesh nectarine cultivar released in 2001. 'Sunbest' trees are semi-upright and vigorous, responding well to open-center pruning systems. 'Sunbest' fruit develop $90-100 \%$ bright red blush over a yellow ground color, are semi-freestone, and resist bacterial spot well. 'Sunbest' is intended as a replacement for 'Sunraycer' nectarine because of its larger and more attractive fruit. 'Sunbest' has an FDP of 85-90 days, and fruit ripen approximately 3 days before 'Sunraycer' nectarine and 'Flordaglo' peach in Gainesville, Florida.

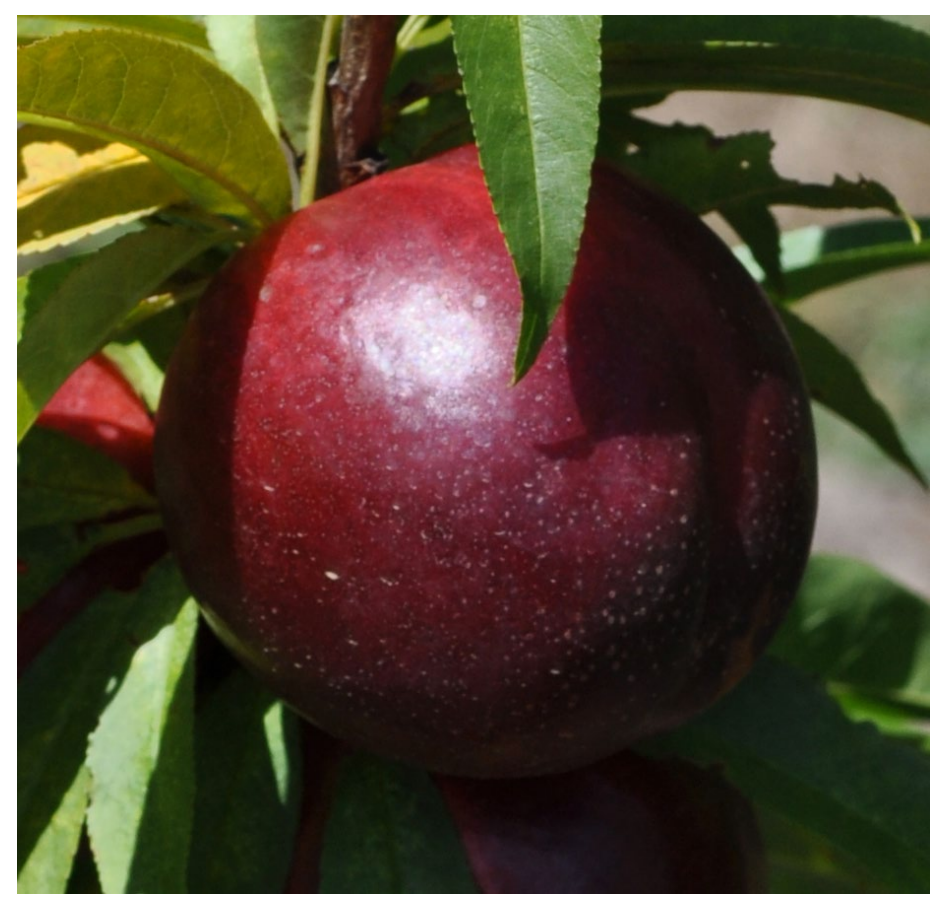

Figure 25. 'Sunbest'

\section{'Sunmist'-300 chill units}

'Sunmist' is a patented melting-flesh nectarine cultivar released in 1994. 'Sunmist' trees are highly vigorous and have a spreading growth habit. Fruit of 'Sunmist' have white flesh, are semi-freestone, and are large for an early ripening cultivar. Fruit develop nearly $100 \%$ red blush and are uniformly symmetrical. 'Sunmist' trees and fruit are highly resistant to bacterial spot. The FDP is 85 days, and the fruit ripen in early May in Gainesville, Florida.

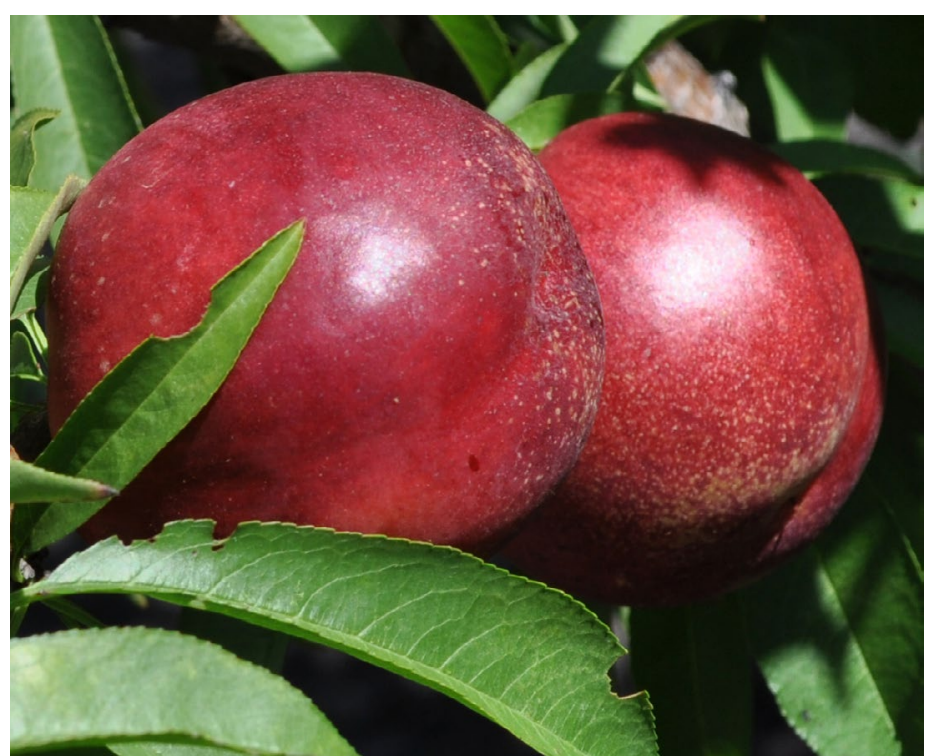

Figure 26. 'Sunmist'

\section{'Suncoast'-375 chill units}

'Suncoast' is a non-patented melting-flesh nectarine cultivar released in 1995. 'Suncoast' trees are vigorous and semi-spreading. Fruit of 'Suncoast' have yellow flesh, develop $80-90 \%$ red blush over a yellow ground color, and are semi-clingstone. 'Suncoast' fruit are slightly oblong with no sharp tips or bulges and tend to be tart. 'Suncoast' leaves and fruit are resistant to bacterial spot. The FDP of 'Suncoast' fruit is 77 days, and fruit ripen in late April to early May in Gainesville, Florida.

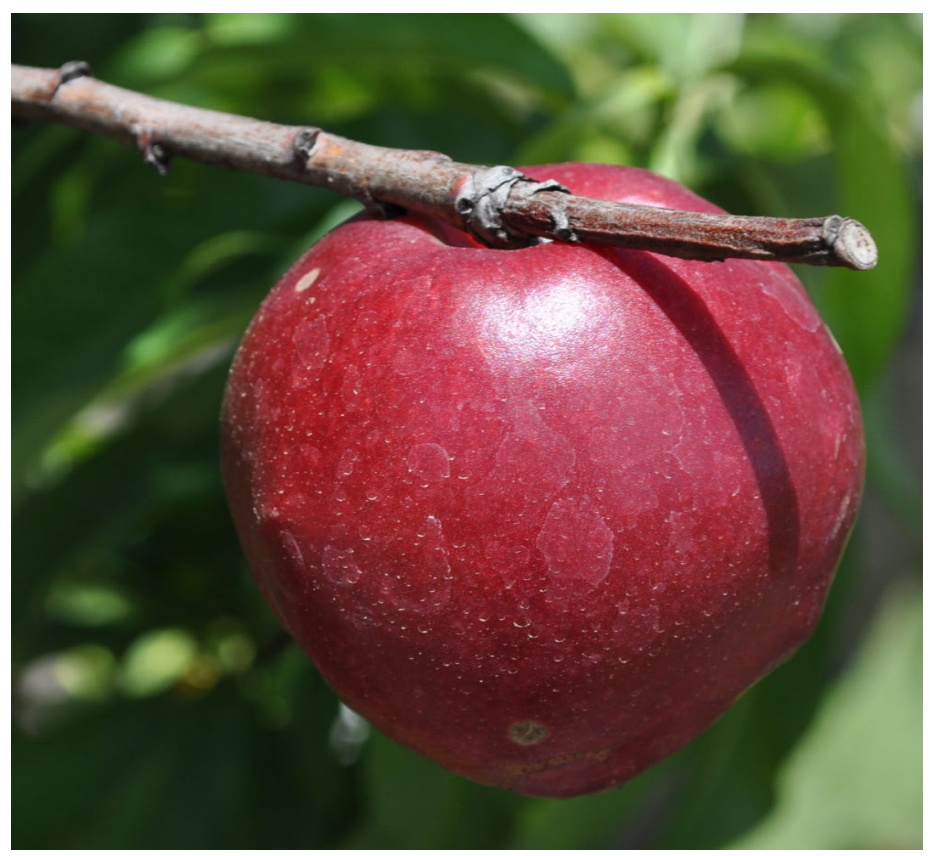

Figure 27. 'Suncoast' 


\section{Cultivar Descriptions}

\section{CENTRAL AND SOUTH CENTRAL FLORIDA}

\section{'Flordaprince' -150 chill units}

'Flordaprince' was released by UF in 1982 and its fruit have melting flesh. It has been a standard low-chill peach cultivar worldwide and is one of the earliest ripening. The fruit develop $80 \%$ red blush with dark red stripes over a yellow ground color. 'Flordaprince' fruit are large, uniformly firm, and yellow, with semi-clingstone pits. The fruit ripen about 7-10 days earlier than 'TropicBeauty' in Gainesville, Florida with an FDP of 78 days.

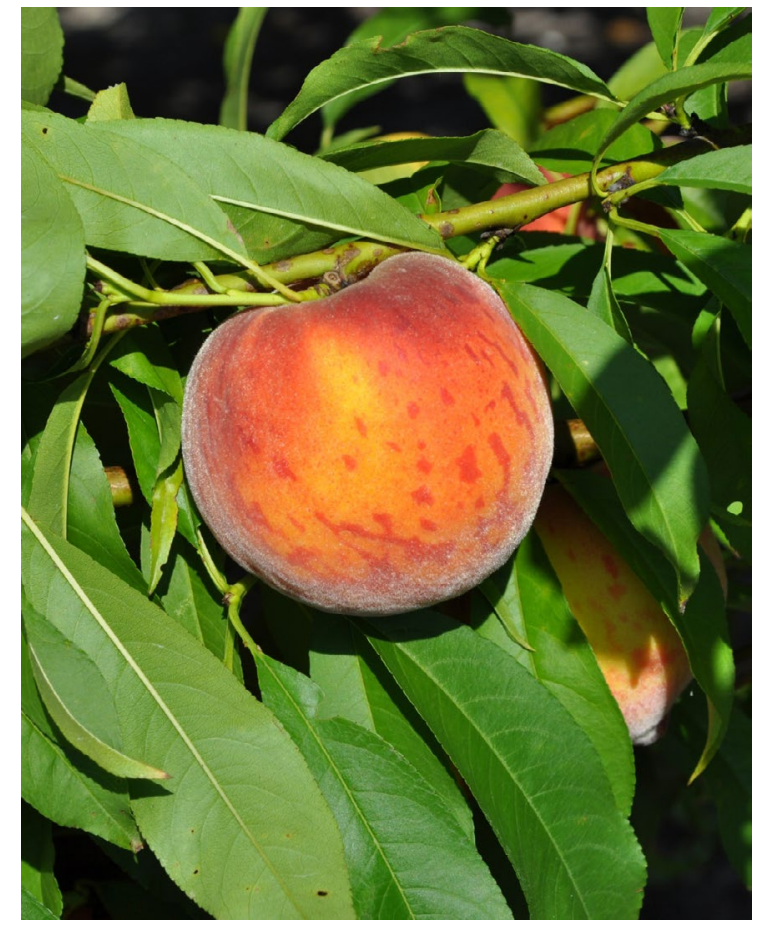

Figure 28. 'Flordaprince'

\section{'Flordaglo'-150 chill units}

'Flordaglo' is a melting-flesh cultivar released by UF in 1988. The fruit develop 50-60\% red blush with stripes, over a white ground color. 'Flordaglo' fruit are early ripening, semi-clingstone, and are bacterial spot resistant. Fruit ripen in early May, approximately 78 days after full bloom. 'Flordaglo' fruit is ideal for backyard or u-pick operations due to the melting flesh texture and its tendency to show bruises and abrasions easily.

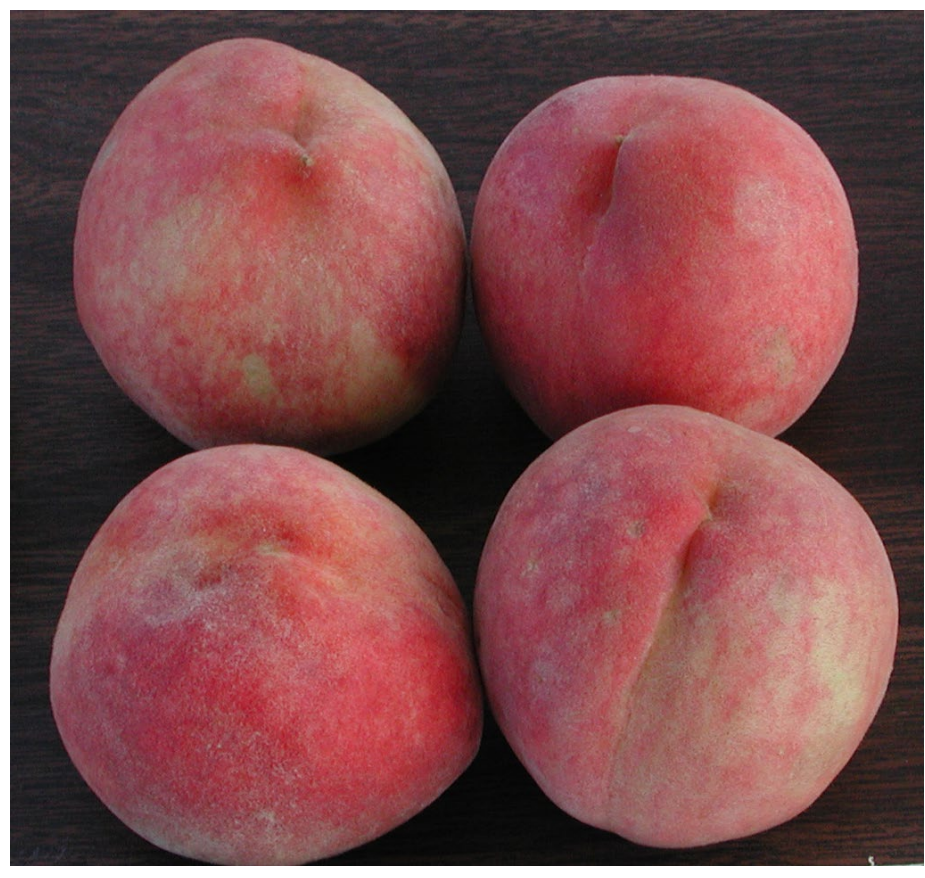

Figure 29. 'Flordaglo'

\section{'UFGold'-200 chill units}

'UFGold' is a non-melting, yellow-flesh clingstone peach released by UF in 1996. 'UFGold' trees bear heavy annual crops of large fruit. Fruit are symmetrical in shape and develop $70-90 \%$ blush over an orange yellow ground color. 'UFGold' fruit ripen approximately 80 days after bloom, in early May (Gainesville, FL).

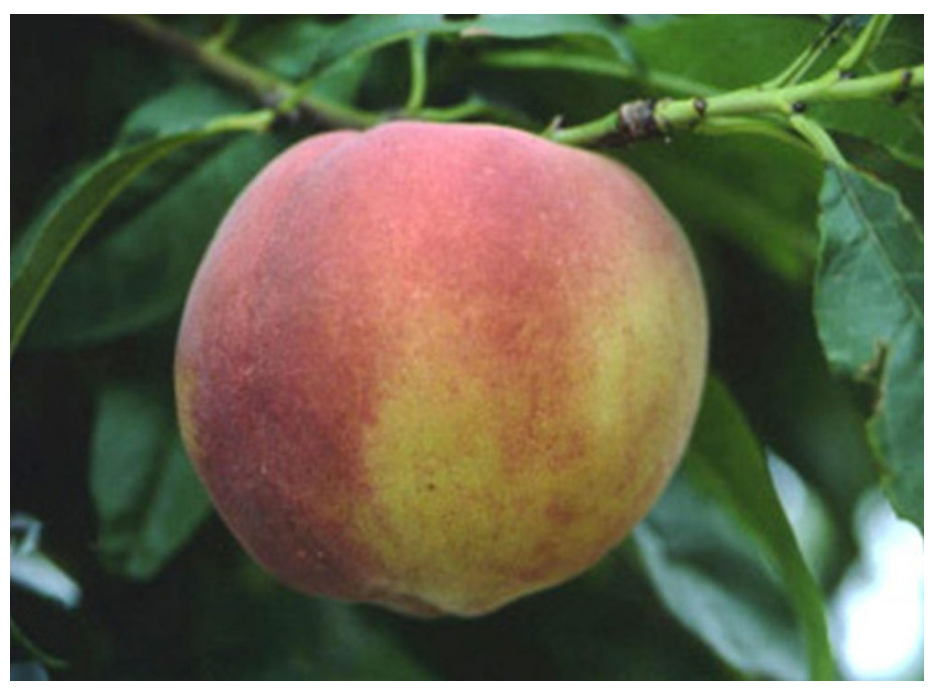

Figure 30. 'UFGold'

\section{'TropicSnow'-225 chill units}

'TropicSnow' was jointly released by UF and Texas A\&M in 1989. Its fruit have white, melting-flesh, semi-freestone pits. 'TropicSnow' fruit develop $40-50 \%$ red blush over a creamy white background and have very low acid combined with excellent sweetness. 'TropicSnow' has a FDP of 90-97 days. 


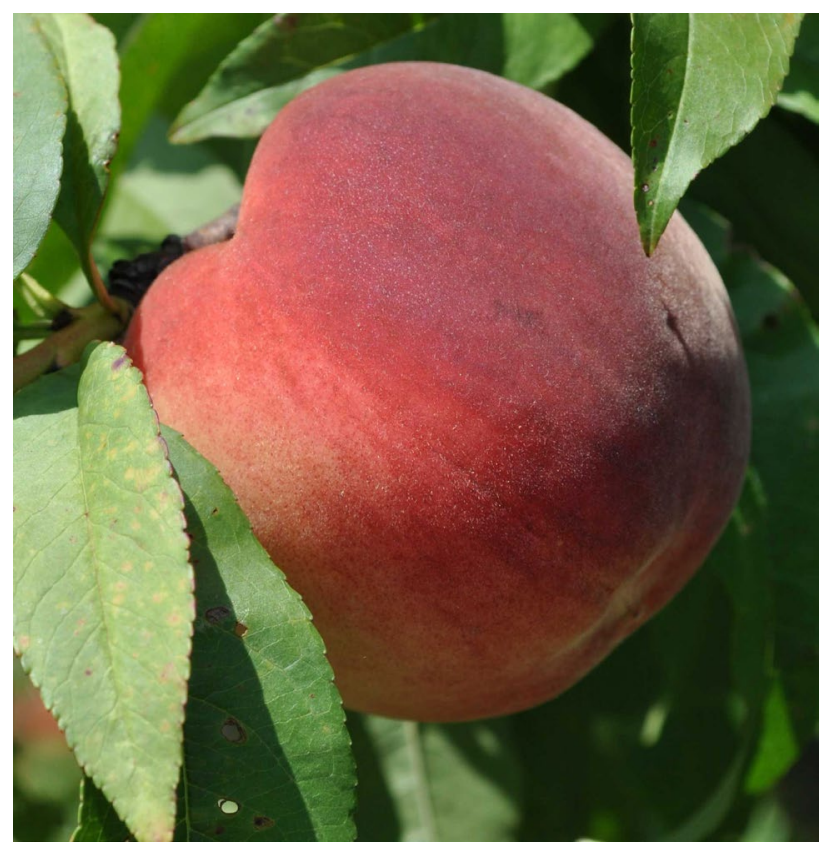

Figure 31. TropicSnow'

\section{References}

Crisosto, C.H. 2002. "How do we increase peach consumption?” Acta Horticulturae 592:601-605.

Fraisse, C.W., and A. Whidden. 2010. "Chill Accumulation Monitoring and Forecasting." AE452. Gainesville: University of Florida Institute of Food and Agricultural Sciences. http://edis.ifas.ufl.edu/ae452
Lopez, G. and Dejong, T.M. 2007. "Spring temperatures have a major effect on early stages of peach fruit growth." Journal of Horticultural Science \& Biotechnology 82:507-512.

Richardson, E.A., S.D. Seeley, and D.R. Walker. 1974. "A model for estimating the completion of rest for 'Redhaven' and 'Elberta' peach trees." HortScience 9 (4):331-332.

Sharpe, R.H., W.B. Sherman, and J.D. Martsolf. 1990. "Peach cultivars in Florida and their chilling requirements." Acta Horticulturae 279:191-197.

Sharpe, R.H., T.E. Webb, and H.W. Lundy. 1954. "Peach cultivar tests." Proceedings of the Florida State Horticultural Society 67:245-246.

Sherman, W.B., P.M. Lyrene, and R.H. Sharpe. 1996. "Low-chill peach and nectarine breeding at the University of Florida." Florida State Horticultural Society 109:222-223.

Weinberger, J.H. 1956. "Prolonged dormancy trouble in peaches in the southeast in relation to winter temperatures." Proceedings of the American Society for Horticultural Science 67:107-112. 
Table 1. Peach and Nectarine Cultivars Recommended for Florida.

\begin{tabular}{|c|c|c|c|}
\hline Cultivar & Date Released & Patent Status & Marketing Potential \\
\hline \multicolumn{4}{|l|}{ Peaches $^{1}$} \\
\hline ‘UFBest' & 2012 & Patented & Commercial \\
\hline ‘UFSun’ & 2004 & Patented & Commercial \\
\hline ‘UFOne' & 2008 & Patented & Commercial \\
\hline 'TropicBeauty' & 1988 & Not Patented & Commercial/Backyard/U-Pick \\
\hline ‘Flordaprince' & 1982 & Not Patented & Backyard/U-pick \\
\hline 'Flordaglo' & 1988 & Not Patented & Backyard/U-pick \\
\hline 'TropicSnow' & 1989 & Not Patented & Backyard/U-pick \\
\hline 'UFBeauty' & 2002 & Patented & Commercial \\
\hline ‘UFGold’ & 1996 & Patented & Backyard/U-pick \\
\hline ‘UFO’ & 2002 & Patented & Commercial/Backyard/U-Pick \\
\hline 'Flordabest' & 2009 & Patented & Commercial \\
\hline ‘UF2000’ & 2000 & Patented & Backyard/U-pick \\
\hline 'UFBlaze’ & 2002 & Patented & Backyard/U-pick \\
\hline 'Flordadawn' & 1989 & Not Patented & Backyard/U-pick \\
\hline ‘UFSharp' & 2006 & Patented & Backyard/U-pick \\
\hline 'Flordacrest' & 1988 & Not Patented & Backyard/U-pick \\
\hline 'Gulfking' & 2004 & Patented & Commercial \\
\hline 'Gulfprince' & 2002 & Patented & Backyard/U-pick \\
\hline 'Gulfcrimson' & 2009 & Patented & Commercial \\
\hline 'Gulfsnow' & 2012 & Patent Pending & Commercial \\
\hline 'UFGlo' & 2009 & Patented & Commercial \\
\hline 'Flordaking' & 1978 & Not Patented & Backyard/U-pick \\
\hline ‘Gulfcrest' & 2004 & Patented & Commercial \\
\hline \multicolumn{4}{|l|}{ Nectarines $^{2}$} \\
\hline 'Sunbest' & 2001 & Patented & Commercial \\
\hline 'Sunraycer' & 1993 & Not Patented & Commercial/Backyard/U-Pick \\
\hline ‘UFRoyal’ & 2009 & Patented & Commercial \\
\hline ‘UFQueen’ & 1998 & Patented & Commercial \\
\hline 'Sunmist' & 1994 & Not Patented & Backyard/U-pick \\
\hline 'Suncoast' & 1993 & Not Patented & Backyard/U-pick \\
\hline \multicolumn{4}{|c|}{$\begin{array}{l}\text { All melting-flesh peach and nectarine cultivars released from the University of Florida breeding program begin with the prefixes } \\
\text { "Florida" and "Sun," respectively. Similarly, all non-melting peach and nectarine cultivars share the prefix, "UF." Releases by the } \\
\text { cooperative University of Florida, University of Georgia, and USDA-ARS have the prefix, "Gulf." }\end{array}$} \\
\hline $\begin{array}{l}{ }^{1} \text { Adapted from } \mathrm{HS} \\
{ }^{2} \text { Adapted from } \mathrm{Ci}\end{array}$ & $\begin{array}{l}\text { ies for Subtropic } \\
\text { lew Plants for Flc }\end{array}$ & $\begin{array}{l}\text { ch Production in } \\
\text { stone Fruit }\end{array}$ & \\
\hline
\end{tabular}


Table 2. Chilling unit accumulation from November 1 to February 15th $\left(32-45^{\circ} \mathrm{F}\right)$. Data generated from the FAWN Temperature Threshold Report Generator: http://fawn.ifas.ufl.edu/tools/temperature_threshold/.

\begin{tabular}{|c|c|c|c|c|c|c|c|c|}
\hline \multirow[t]{2}{*}{ Year } & \multirow[b]{2}{*}{$\begin{array}{l}\text { Tallahassee } \\
\text { (Monticello)* }^{*}\end{array}$} & \multicolumn{7}{|c|}{ Location } \\
\hline & & $\begin{array}{c}\text { Jacksonville } \\
\text { (Macclenny) }^{*}\end{array}$ & Alachua & $\begin{array}{l}\text { Orlando } \\
\text { (Avalon)* }\end{array}$ & Lake Alfred & Frostproof & Fort Pierce & Immokalee \\
\hline $2000-2001$ & $N A^{* *}$ & NA & 582 & 374 & 314 & NA & 210 & 202 \\
\hline 2001-2002 & NA & NA & 391 & 151 & 134 & NA & 88 & 86 \\
\hline 2002-2003 & NA & 714 & 712 & 368 & 317 & NA & 253 & 247 \\
\hline 2003-2004 & 647 & 490 & 516 & 211 & 192 & NA & 103 & 177 \\
\hline 2004-2005 & 571 & 510 & 495 & 182 & 170 & NA & 129 & 174 \\
\hline 2005-2006 & 570 & 529 & 530 & 208 & 193 & 162 & 147 & 184 \\
\hline 2006-2007 & 540 & 442 & 419 & 82 & 101 & 61 & 64 & 66 \\
\hline 2007-2008 & 512 & 440 & 385 & 120 & 123 & 72 & 49 & 66 \\
\hline 2008-2009 & 517 & 505 & 490 & 251 & 246 & 160 & 138 & 196 \\
\hline 2009-2010 & 664 & 519 & 503 & 356 & 306 & 281 & 235 & 237 \\
\hline 2010-2011 & 778 & 679 & 646 & 352 & 371 & 295 & 223 & 227 \\
\hline 2011-2012 & 452 & 333 & 343 & 127 & 115 & 108 & 86 & 94 \\
\hline
\end{tabular}


Table 3. Chill unit requirements, flower and leaf characteristics, disease resistance, and commercial/backyard suitability of lowchill peach and nectarine cultivars from the University of Florida stone fruit breeding program.

\begin{tabular}{|c|c|c|c|c|c|c|c|c|}
\hline & & \multicolumn{2}{|c|}{$\begin{array}{l}\text { January mean } \\
\text { temperature }\end{array}$} & \multirow[t]{2}{*}{$\begin{array}{c}\text { Estimated chill } \\
\text { units }\end{array}$} & \multirow[t]{2}{*}{$\begin{array}{l}\text { Flower } \\
\text { type }^{y}\end{array}$} & \multirow[t]{2}{*}{$\begin{array}{l}\text { Flower } \\
\text { bud set }^{\mathrm{x}}\end{array}$} & \multirow[t]{2}{*}{ Leaf glands ${ }^{w}$} & \multirow[t]{2}{*}{$\begin{array}{l}\text { Bacterial spot } \\
\text { resistance }^{v}\end{array}$} \\
\hline & & ${ }^{\circ} \mathrm{F}$ & ${ }^{\circ} \mathrm{C}$ & & & & & \\
\hline \multirow[t]{23}{*}{ Peach } & 'UFSun' & 63.3 & 17.4 & 100 & $S$ & 10 & $\mathrm{R}$ & 7 \\
\hline & 'UFBest' & 66.2 & 19.0 & 100 & $\mathrm{~S}$ & 10 & $\mathrm{R}$ & 10 \\
\hline & 'UFOne' & 63.5 & 17.5 & 150 & $\mathrm{~S}$ & 8 & G & 10 \\
\hline & 'TropicBeauty' & 64.0 & 17.8 & 150 & $S$ & 8 & $\mathrm{R}$ & 5 \\
\hline & 'Flordaprince' & 64.0 & 17.8 & 150 & $S$ & 8 & $\mathrm{R}$ & 4 \\
\hline & 'Flordaglo' & 64.0 & 17.8 & 150 & $\mathrm{~S}$ & 9 & $\mathrm{R}$ & 8 \\
\hline & 'UFBeauty' & 59.0 & 15.0 & 150 & $\mathrm{~S}$ & 8 & G & 10 \\
\hline & 'UFGold' & 62.0 & 16.7 & 200 & $S$ & 9 & $\mathrm{R}$ & 9 \\
\hline & 'TropicSnow' & 61.0 & 16.1 & 225 & $S$ & 9 & $\mathrm{R}$ & 8 \\
\hline & 'UFO' & 61.0 & 16.1 & 250 & NS & 8 & $\mathrm{R}$ & 10 \\
\hline & 'Flordabest' & 61.0 & 16.1 & 250 & $\mathrm{~S}$ & 10 & $\mathrm{R}$ & 9 \\
\hline & 'UF2000' & 59.0 & 15.0 & 300 & $S$ & 9 & $\mathrm{R}$ & 9 \\
\hline & 'UFBlaze' & 62.0 & 16.7 & 300 & $\mathrm{~S}$ & 8 & G & 10 \\
\hline & 'Flordadawn' & 62.0 & 16.7 & 200 & $S$ & 9 & G & 10 \\
\hline & 'UFSharp' & 59.0 & 14.9 & 325 & $\mathrm{~S}$ & 9 & G & 9 \\
\hline & 'Flordacrest' & 58.0 & 14.4 & 350 & $S$ & 8 & G & 10 \\
\hline & 'Gulfking' & 56.0 & 13.5 & 350 & $\mathrm{~S}$ & 9 & $\mathrm{R}$ & 10 \\
\hline & 'Gulfsnow' & 53.0 & 13.0 & 400 & $\mathrm{~S}$ & 10 & G & 10 \\
\hline & 'UFGlo' & 53.0 & 13.0 & 400 & $S$ & 10 & $\mathrm{R}$ & 10 \\
\hline & 'Gulfprince' & 53.0 & 13 & 400 & $\mathrm{~S}$ & 9 & $\mathrm{R}$ & 10 \\
\hline & 'Gulfcrimson' & 56.0 & 13.5 & 400 & $\mathrm{~S}$ & 9 & $\mathrm{R}$ & 10 \\
\hline & 'Flordaking' & 58.0 & 14.4 & 450 & NS & 6 & G & 10 \\
\hline & 'Gulfcrest' & 54.0 & 13.6 & 525 & NS & 9 & G & 10 \\
\hline \multicolumn{9}{|c|}{ Nectarine } \\
\hline & 'Sunbest' & 61.0 & 16.6 & 225 & $\mathrm{~S}$ & 9 & $\mathrm{R}$ & 9 \\
\hline & 'UFQueen' & 61.0 & 16.1 & 250 & NS & 9 & $\mathrm{R}$ & 8 \\
\hline & 'Sunraycer' & 61.0 & 16.1 & 250 & NS & 8 & $\mathrm{R}$ & 10 \\
\hline & 'UFRoyal' & 61.0 & 16.1 & 250 & $\mathrm{~S}$ & 9 & $\mathrm{R}$ & 10 \\
\hline & 'Sunmist' & 60.0 & 15.6 & 300 & $\mathrm{~S}$ & 8 & G & 8 \\
\hline & 'Suncoast & 58.0 & 14.0 & 375 & NS & 9 & $\mathrm{R}$ & 10 \\
\hline
\end{tabular}

${ }^{z}$ Adapted from Weinberger (1956) and Sharpe (1990). Areas with this Jan. mean temperature or a lower one will provide sufficient chilling to grow this peach successfully.

y $\mathrm{S}=$ showy, NS = non-showy

$\times 1=10 \%$ flower bud set to $10=100 \%$ flower bud set

${ }^{\mathrm{w}} \mathrm{G}=$ globose, $\mathrm{R}=$ reniform

${ }^{\vee} 1=$ least resistant to $10=$ most resistant 


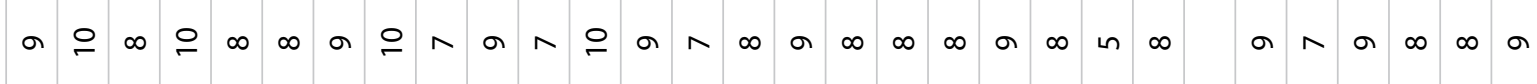

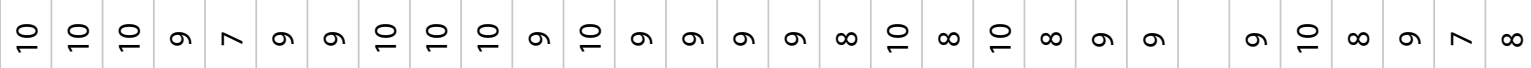

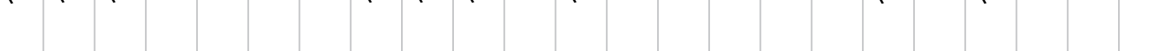

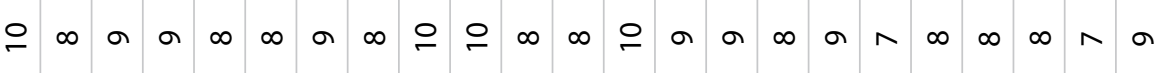$$
\text { a으 } a ㅇ ㅡ
$$

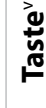

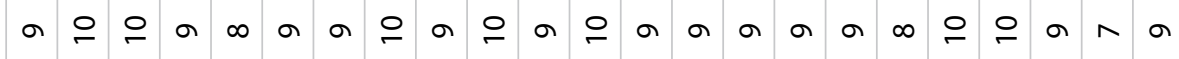

a은 $a$ a $a$ a

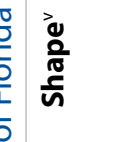

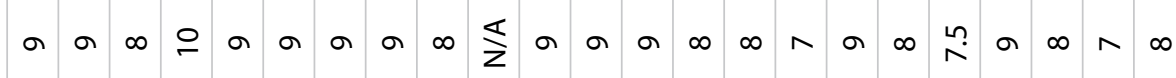

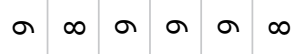

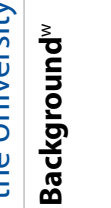

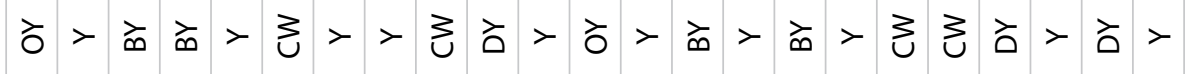

$>>\grave{\infty}>3>$

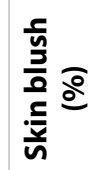

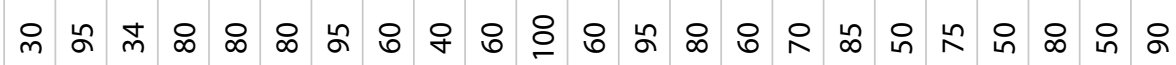

노 ஃ 요 ๓

$\frac{5}{\underline{y}} \frac{x}{\frac{0}{0}}$

$>>>>3>>3>>>>>>>>33>>>3$

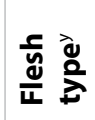

$\sum \sum \sum \sum \sum \sum \sum \sum \sum \sum \sum \sum \sum \sum \sum \sum \sum \sum \sum \sum \sum \sum \sum \sum \sum$

$\sum \sum \sum \sum \sum \Sigma$

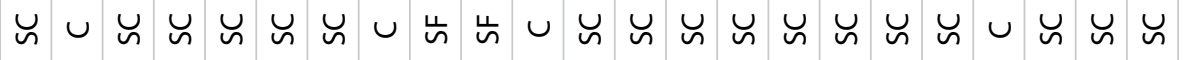

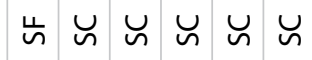

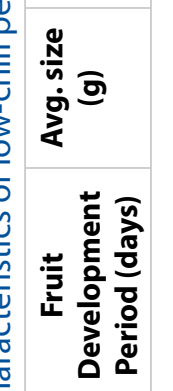

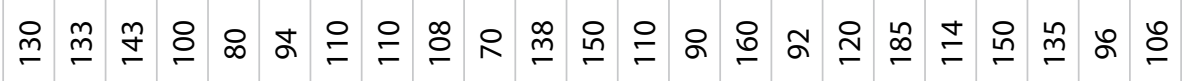

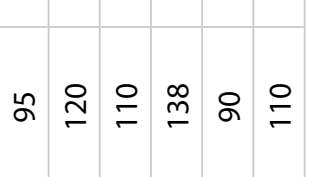

○ம

$\infty$ ๓n

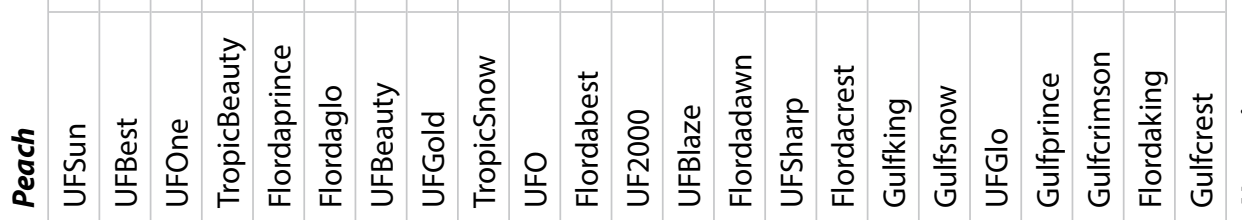

